\title{
Preliminary Materials Transport Plan for the Plutonium Immobilization Plant
}

J. M. Gilkison, G. M. Dyches, W. J. Randall, and J. H. Steed

Westinghouse Savannah River Company Aiken, SC

January 26, 2000

U.S. Department of Energy

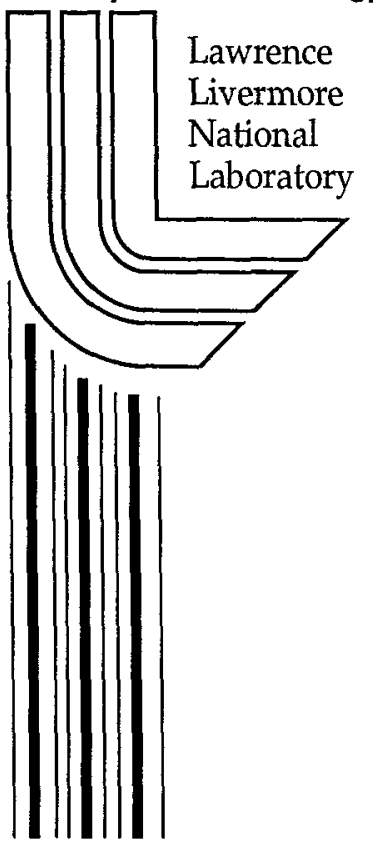




\section{DISCLAIMER}

This document was prepared as an account of work sponsored by an agency of the United States Government. Neither the United States Government nor the University of California nor any of their employees, makes any warranty, express or implied, or assumes any legal liability or responsibility for the accuracy, completeness, or usefulness of any information, apparatus, product, or process disclosed, or represents that its use would not infringe privately owned rights. Reference herein to any specific commercial product, process, or service by trade name, trademark, manufacturer, or otherwise, does not necessarily constitute or imply its endorsement, recommendation, or favoring by the United States Government or the University of California. The views and opinions of authors expressed herein do not necessarily state or reflect those of the United States Government or the University of California, and shall not be used for advertising or product endorsement purposes.

Work performed under the auspices of the U. S. Department of Energy by the University of California Lawrence Livermore National Laboratory under Contract W-7405-Eng-48.

This report has been reproduced

directly from the best available copy.

Available to DOE and DOE contractors from the

Office of Scientific and Technical Information

P.O. Box 62, Oak Ridge, TN 37831

Prices available from (423) 576-8401

http://apollo.osti.gov/bridge/

Available to the public from the

National Technical Information Service

U.S. Department of Commerce

5285 Port Royal Rd.,

Springfield, VA 22161

http://www.ntis.gov/

OR

Lawrence Livermore National Laboratory

Technical Information Department's Digital Library

http://www.llnl.gov/tid/Library.html 
January 26, 2000

PIP-00-092

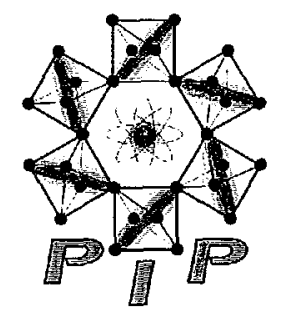

\section{Preliminary Materials Transport Plan}

For the

Plutonium Immobilization Plant

Prepared By

J. M. Gilkison

G. M. Dyches

W. J. Randall

J. H. Steed

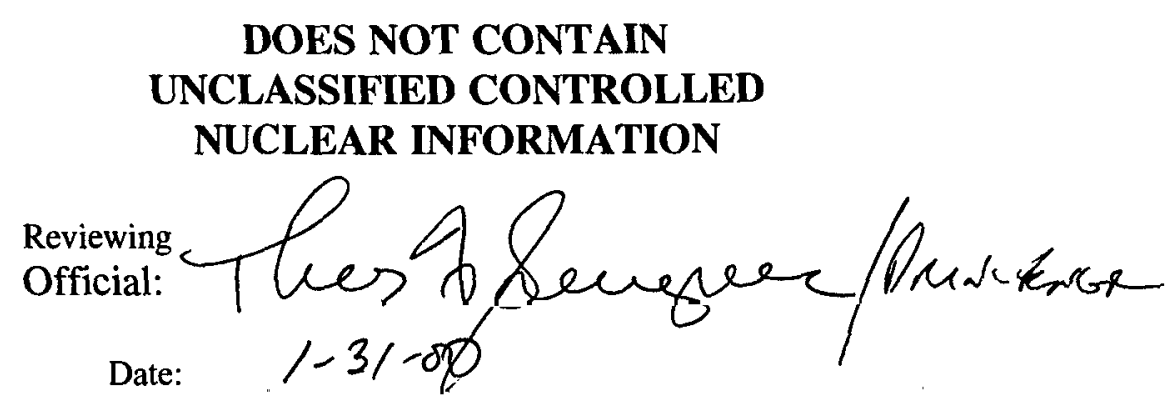

Westinghouse Savannah River Company

Savannah River Site

Aiken, SC 29808 


\section{PIP Approval Sheet \\ Material Transport Plan}

Prepared By:

Signature: W. D. Randall 7-12-00

Name: W. J. Randall, WSRC Date

Approved: Task Leader

Signature: Ephedede of 7-14-00

Name: E. P. Maddux, WSRC Date

Approved: Activity Leader

Signature:

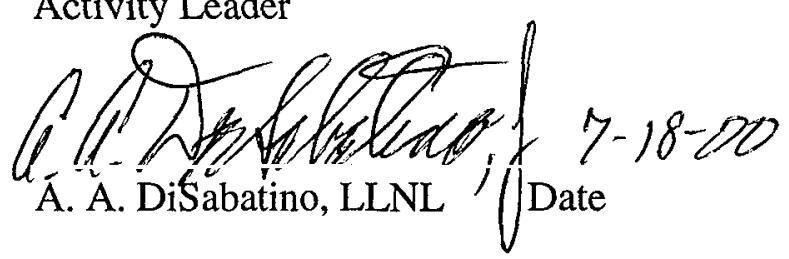

Name: $\quad$ Á. A. DiSabatino, LLNL ' Date

Approved: Program Manager

Signature:

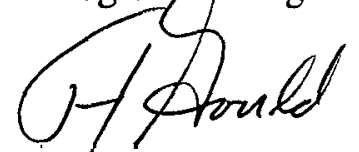

Name:

T. H. Gould, LLNL

$7 / 19 / 00$

Date 
Preliminary Materials Handling Plan for the

Revisoin 0

Plutonium Immobilization

January 26,2000

Page is of 58

APPROVAL

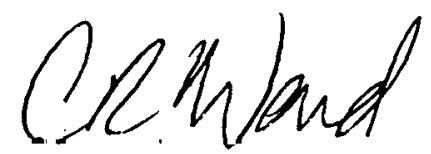

C. R. Ward

Manager, EES, Remote Specialty Equipment

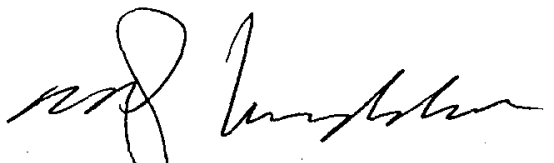

E. P. Maddox

Manager, NMSS, New Missions Programs
Date $1 / 27 / 00$

Date $1 / 31 / 00$ 


\section{TABLE of CONTENTS}

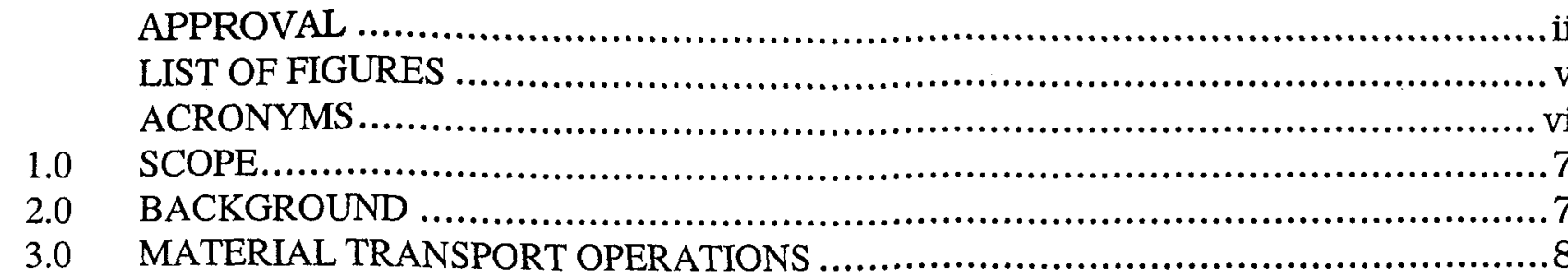

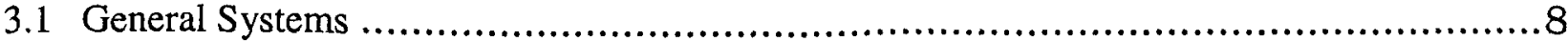

3.2 Plutonium-Bearing Material Transport System ….............................................

3.2.1 Feed Material Receiving and Storage Operations ..................................... 9

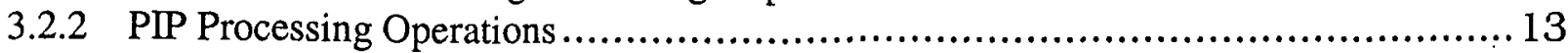

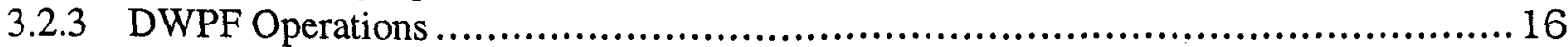

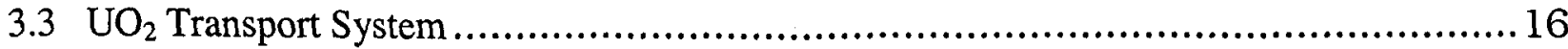

3.4 Non-Nuclear Feed Material, Process Consumables, and Non-Process Materials Transport

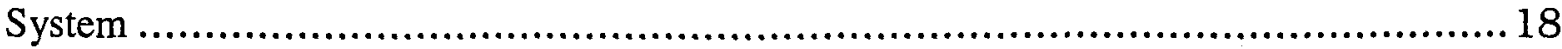

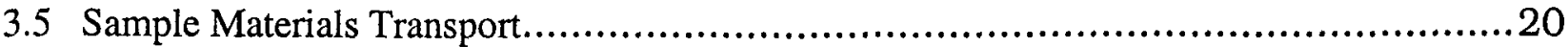

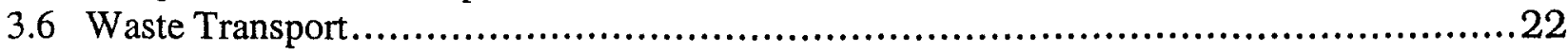

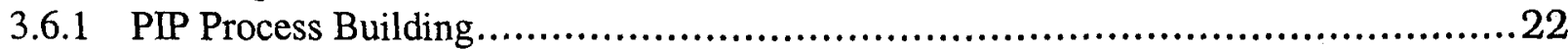

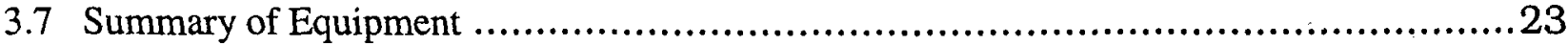

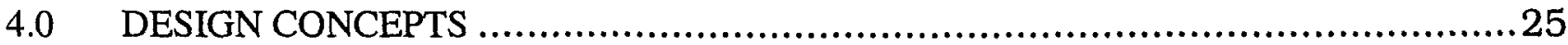

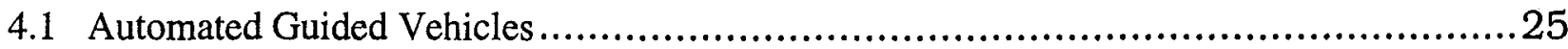

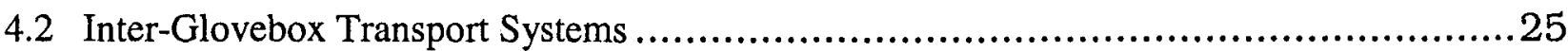

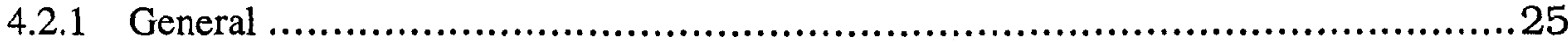

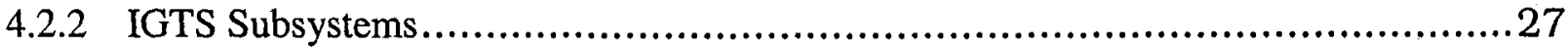

4.2.3 Sample Vacuum Transport System......................................................35

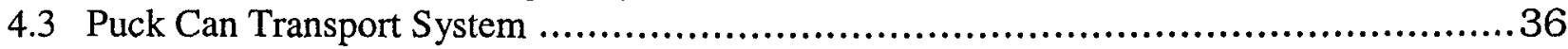

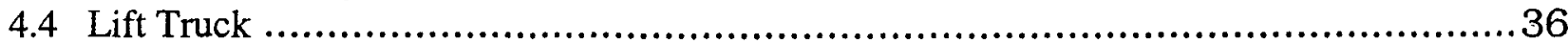

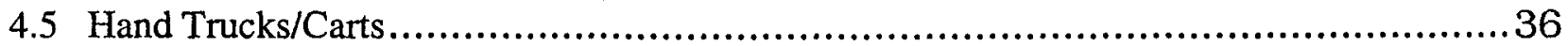

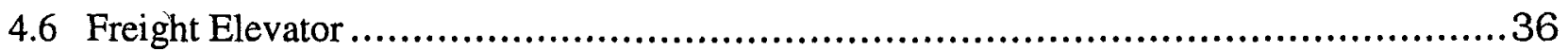

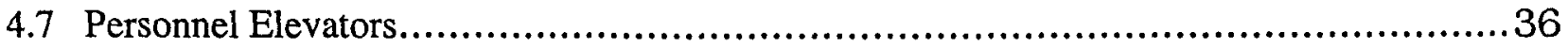

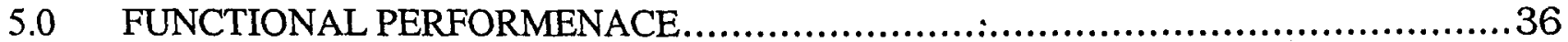

5.1 Functional Classifications .................................................................. 36

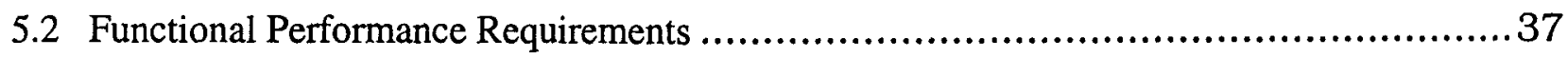

5.2.1 Facility-Wide Functional Performance Requirements .................................37

5.2.2 Plutonium-Bearing Material Transport System .........................................4 47

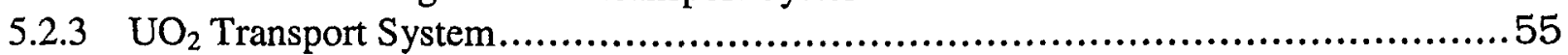

5.2.4 Non-Nuclear Feed Material, Process Consumables, and Non-Process Materials

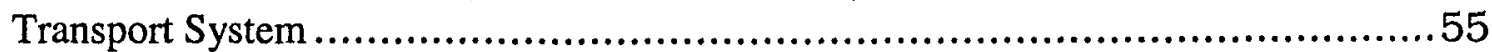

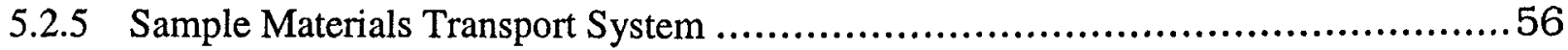

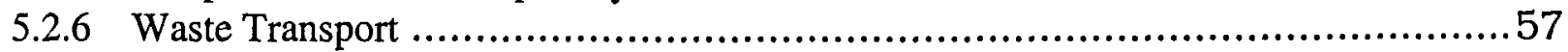

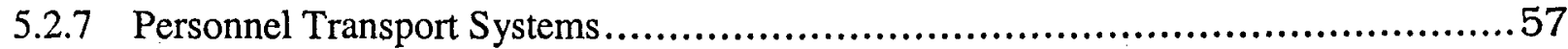

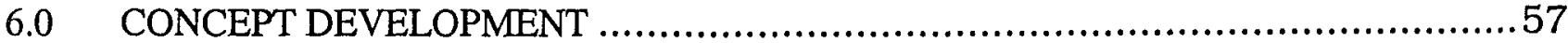

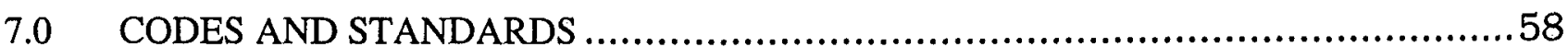

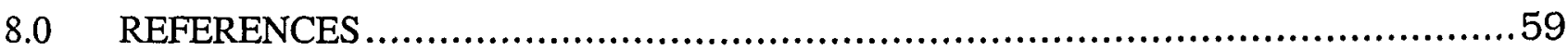

Attachment - Drawing L-202-2 .................................................. 58 


\section{List of Figures}

Title

1A Material Movements Flow Sheet for Plutonium-Bearing Feed Materials

1B Material Movements Flow Sheet for Plutonium Feed Materials .10

2 Material Movements Flow Sheet for Uranium Oxide Feed Materials 15

3 Material Movements Flow Sheet for Non-Nuclear Feed Materials . .17

4 Material Movement Flow Sheet for Samples 19

5 .........Schematic of Overhead Transport System Cart. .27

6 Sketch of Prototype HYDOX Basket and Bucket Assembly .31

7 Sketch of Prototype IGTS Standard Can and Bucket Assembly.

8 Sketch of Prototype IGTS Bucket. 


\section{Acronyms}

$\begin{array}{ll}\text { A/E } & \text { Architect/Engineer } \\ \text { AGV } & \text { Automated Guided Vehicle } \\ \text { ALARA } & \text { As-Low-As-Reasonably-Achievable } \\ \text { AM } & \text { Accountability Measurements } \\ \text { CCTV } & \text { Closed-Circuit Television } \\ \text { CRT } & \text { Cargo Restraint Trasnporter } \\ \text { DOCDR } & \text { Design-Only Conceptual Design Report } \\ \text { DOE } & \text { U. S. Department of Energy } \\ \text { DOT } & \text { U. S. Department of Transportation } \\ \text { DWPF } & \text { Defense Waste Processing Facility } \\ \text { FDD } & \text { Facility Design Description } \\ \text { gm } & \text { Gram } \\ \text { HEPA } & \text { High-Efficiency Particulate Filter } \\ \text { HVAC } & \text { Heating, Ventilating, and Air Conditioning } \\ \text { IGTS } & \text { Inter-Glovebox Transport System } \\ \text { kg } & \text { Kilogram } \\ \text { lb } & \text { Pound } \\ \text { MC\&A } & \text { Material Control and Accountability } \\ \text { NDA } & \text { Nondestructive Assay } \\ \text { NRC } & \text { Nuclear Regulatory Commission } \\ \text { PIP } & \text { Plutonium Immobilization Plant } \\ \text { PLC } & \text { Programmable Logic Controller } \\ \text { Pu } & \text { Plutonium } \\ \text { SDD } & \text { System Design Description } \\ \text { SSC } & \text { Systems, Structures, and Components } \\ \text { TBD } & \text { To be Determined } \\ \text { TCP/IP } & \text { Transmission Control Protocol/Internet Protocol } \\ \text { UBC } & \text { Uniform Building Code } \\ \text { UO } 2 & \text { Uranium Oxide } \\ & \end{array}$




\subsection{SCOPE}

This Materials Transport Plan defines the methodology for moving process and non-process materials within the Plutonium Immobilization Plant (PIP) operations. The scope of the plan includes the movement of materials between plant operational units (gloveboxes or operational areas/rooms within the plant). The movements of materials within the various plant operational units are described in the System Design Description prepared for the individual units.

The plan provides a design concept for transporting each type of material including the containerization used during the movements. Further, the plan identifies the high-level functions and requirements for movements of the materials.

\subsection{BACKGROUND}

The Plutonium Immobilization Plant (PIP) will receive plutonium-bearing feed materials from various locations throughout the DOE Complex (including the SRS). The feed materials will be received in oxide form or as metals and alloys. The PIP will:

- prepare the plutonium-bearing feed materials for immobilization,

- mix the plutonium-bearing materials with uranium oxide and ceramic precursor material, .

$\square$ immobilize the materials in a ceramic form,

$\square$ encapsulate the ceramic material in a matrix of high-level waste glass poured into the canisters at DWPF

口 store the glass-filled canisters until shipment off-site to a national waste repository.

All plutonium-bearing materials received in DOE-STD-3013-96 storage containers (3013) packaged in DOE approved shipping packages - primarily the 9975 shipping package. The materials receiving and storage area of the PIP will perform all require materials receipt operations including unloading the delivery trucks, performing MC\&A activities, lag storing shipping packages, removing the 3013s from shipping packages, and storing the $3013 \mathrm{~s}$ until the materials is required by the PIP immobilization process. The materials will be retrieved from the PIP storage vault based on production requirements and transferred to the PIP materials unpackaging and sorting glovebox.

The PIP will remove the materials from their containment vessels, prepare the materials for immobilization, mix the plutonium-bearing materials with other nuclear and non-nuclear process feed materials, and convert the mixture by sintering into a mineral-like form (ceramic pucks). The pucks will be placed in weld-sealed cans, the cans inserted into perforated tubes (magazines), and the magazines installed into a Defense Waste Processing Facility (DWPF) canister. The can-in-canister assembly will be transported to DWPF where the canister will be filled with high-level waste glass and then stored until shipped off-site to a national waste repository. Additional information regarding the PIP operations is provided in the PIP DOCDR, Reference 1.

Non-plutonium-bearing nuclear and non-nuclear feed materials will include uranium oxide $\left(\mathrm{UO}_{2}\right)$, ceramic precursors, binders, and lubricants. The $\mathrm{UO}_{2}$ will be received directly through the south dock of the PIP Process Building. The non-nuclear process feed materials will be received at a commodities warehouse and then transferred as batches into the PIP through the south dock and then to storage areas within the PIP. 
Other process consumables and non-process materials will be handled similarly to the nonnuclear feed materials by being first received at the commodities warehouse and then moved to storage inside the PIP through the south dock.

Waste materials containing plutonium will be transported by two generalized methods. Those waste items generated by glovebox operations will be transported by the inter-glovebox transport system (IGTS) from the various unit operations to the waste handling area. Large waste items and waste items generated in areas not serviced by the IGTS will be bagged out of the confinement systems and moved via hand truck or cart to Waste Handling. Boxed or drummed waste from waste handling will be moved by hand truck, cart or lift truck to the PIP south dock for shipment from the facility.

\subsection{MATERIAL TRANSPORT OPERATIONS}

\subsection{General Systems}

For this materials transport plan, materials movements in the PIP have been categorized into five major systems based on the general type of materials to be transported. Each of these major transport systems is made up of a number of subsystems. These systems and their major subsystems are:

\section{Process Material Transport System}

- Lift trucks with attachable drum handling head

- Automated guided vehicles

- Inter-glovebox transport system

- Puck can transport system

\section{$\mathrm{UO}_{2}$ Transport System}

- Lift truck with attachable drum handling head

\section{Non-Nuclear Feed Material, Process Consumables, and Non-Process Materials Transport}

\section{System}

- $\quad$ Lift trucks

- Site trucks

- Hand truck/carts

- Gas cylinder hand truck

\section{Sample Materials Transport System}

- sample vacuum transport system

- Hand trucks/carts

- Site trucks

\section{Waste Transport}

- Inter-glovebox transport system

- Hand trucks/carts

- Lift truck

\section{Personnel Transport Systems}


- Personnel elevators

\subsection{Plutonium-Bearing Material Transport System}

An integrated flow diagram for all movements of plutonium-bearing materials for PIP operations is provided in Figures 1A and 1B. The inter-operations unit movements of plutonium-bearing materials depicted in these figures have been categorized into two sections - PIP and DWPF operations.

\subsubsection{Feed Material Receiving and Storage Operations}

DOE/DOT approved shipping packages with plutonium-bearing feed materials will be delivered by SSTs or site trucks and received through an enclosed receiving dock. The feed materials will be in 3013 storage containers packaged in DOE approved shipping packages. The shipping packages will be received as individual shipping packages or in CRTs (up to 4 per CRT). All movements of shipping packages will be made using a lift truck. The lift truck will be equipped with attachable heads to allow handling of CRTs (CRT handling head) or individual shipping packages (drum handling head).

Movement of shipping packages includes:

a. Unloading CRTs or individual shipping packages from SSTs and site trucks and moving to the staging area.

b. Transport from the staging area to the shipping package storage area. (Note: CRTs may be unloaded in the staging area prior to transport to the storage area or can be stored in the shipping package storage area and returned later to the staging area for unloading.)

c. Transport from the shipping package storage area to the MC\&A confirmatory measurements area and returning the Shipping package storage area or to the shipping package unpackaging area.

d. Transport from the shipping package storage area to the shipping package unpackaging area.

As required to meet production needs or to satisfy MC\&A requirements, the shipping packages will be moved from the shipping package storage area to the shipping package unpackaging area using a drum handler lift truck. The 3013 shipping package containment vessels will be removed from the shipping packages and will be transferred via a conveyor system into the accountability measurements (AM) area. In the AM area, an over head robotic gantry crane ${ }^{1}$ will shuffle the 3013 containers between the various measurements equipment; e.g., calorimeters, multiplicity counters, etc., and automatically load the 3013 containers into the assay instruments. Then, after completion of the accountability measurements operations, the crane will deposit the containers on a conveyor that will transfer the container into the storage vault portal. An automated guided vehicle (AGV) will retrieve the 3013 containment vessels from the conveyer and will transport the containers to a

1 The robotic crane and AGV are outside the scope of this materials transport document. The functions of the crane and AGV, respectively, are presented in the Systems Design Descriptions for the accountability measurements area and the storage vault. 


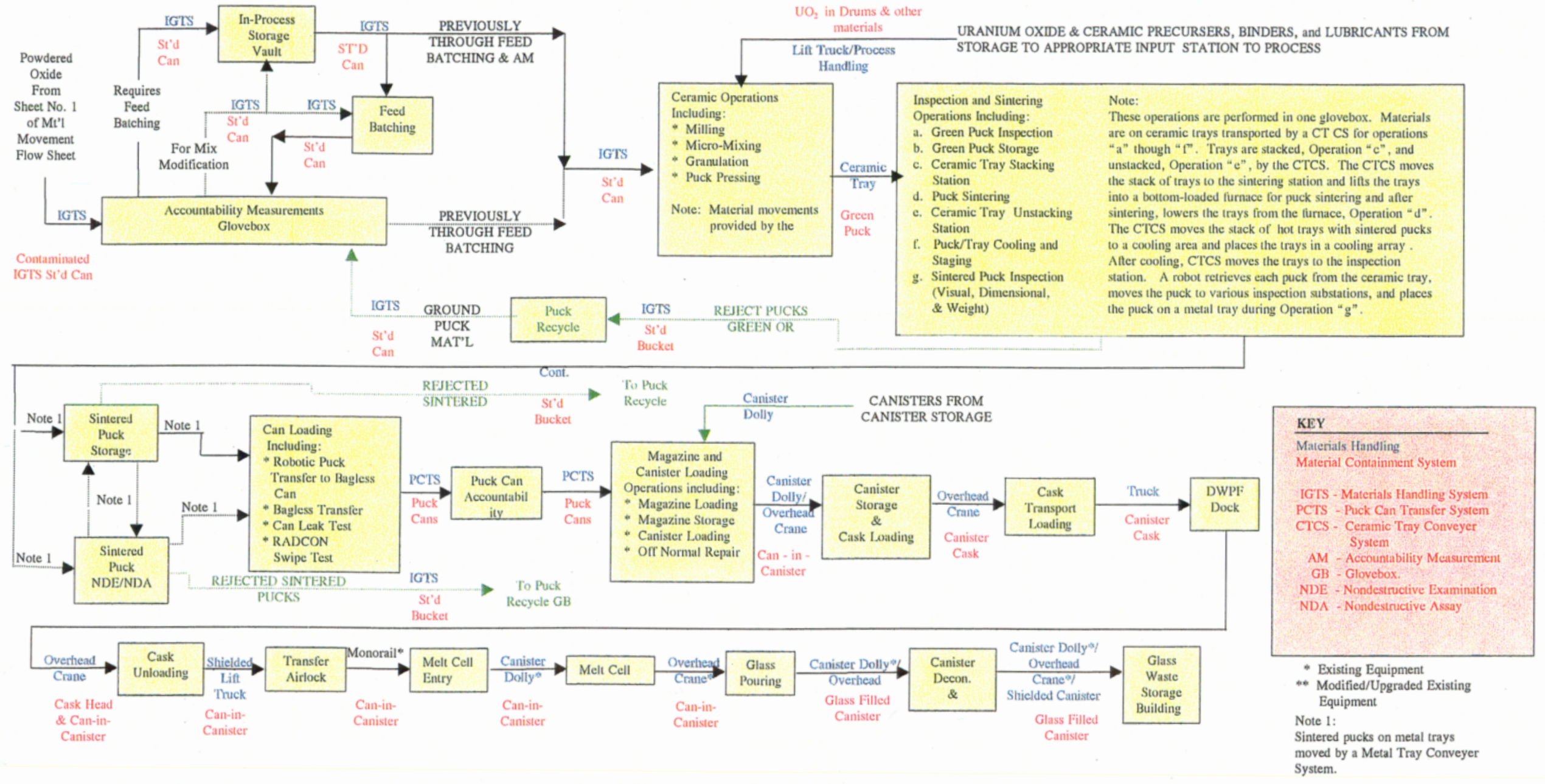

Figure 1B. Material Movements Flow Sheet for Plutonium Feed Materials 
storage position. Subsequently, when material is needed for PIP immobilization operations, the AGV will retrieve a storage container and transport the container to an inter-glovebox transport system (IGTS) pick-up station located in the storage vault portal. The IGTS will move the storage container to the PIP materials unpackaging and sorting glovebox.

In addition, the PIP feed material receiving and storage operations will reassemble empty shipping packages and will store the empty shipping packages and CRTs until they are shipped from the facility.

Summary of Feed Material Receiving and Storage Area Materials Handling Operations Inter-operational unit material movements in the PIP Feed Material Receiving and Storage operations will use a combination of following listed materials handling equipment:

\begin{tabular}{|l|l|}
\hline \multicolumn{1}{|c|}{$\begin{array}{c}\text { Materials Handling } \\
\text { Equipment }\end{array}$} & Container/Item Transported \\
\hline $\begin{array}{l}\text { Lift Truck }{ }^{2} \text { with attachable } \\
\text { CRT handler head or drum } \\
\text { handler head }\end{array}$ & Shipping packages on CRTs \\
\hline Conveyor & $\begin{array}{l}\text { Standard or reusable 3013 or } \\
\text { empty reusable 3013 } \\
\text { containment vessels }\end{array}$ \\
\hline AGV & $\begin{array}{l}\text { Loaded standard 3013 and } \\
\text { reusable 3013 containment } \\
\text { vessels } \\
\text { Empty reusable 3013 } \\
\text { containment vessels }\end{array}$ \\
\hline
\end{tabular}

Notes

1. Lift truck may require shielding to protect the operator from radiological exposures.

\subsubsection{PIP Processing Operations}

\subsubsection{Inter-Glovebox Transport System}

An uncontaminated (clean) section of the IGTS will move all standard 3013 containers from the storage vault to the materials unpackaging and sorting area.

The unit operations in the materials unpackaging and sorting area will open the 3013 containment vessels and place the feed materials into appropriate IGTS standard containers. Metals and alloys will be placed in HYDOX basket/bucket assemblies and oxides into standard containers. These containers will be transported by IGTS transport carts through a network of overhead tunnels that are part of the IGTS system that interconnects all PIP conversion unit operation areas including delivery of the materials to the first stage immobilization ceramification system (stack). The PIP process operational units interfacing with the IGTS system include: 
Metals and Alloys

a. Unpackaging and sorting

b. Metal conversion

\section{Oxides}

a. Unpackaging and sorting

b. Oxide crush and grind

c. Oxide wash

d. Calcining

e. Materials characterization*

f. In-process storage vault*

g. Accountability measurements*

h. Feed batching and blending*

i. Ceramic operations*

* Includes oxides generated by the metal conversion unit operations

\section{Solid Waste}

a. All process operational units and waste management

b.

Note that the contaminated IGTS will transport materials between the PIP conversion, ceramification, and waste unit operations only (Drawing L-202-2). Movement of materials within each unit operations is not included in the scope of this material handling plan and will be described in the System Design Description reports for the respective operational units. The design of the IGTS shall be sufficiently versatile that materials can be transported, as needed, from any of the conversion operational unit areas to any other conversion operational unit area. This versatility will require that bi-directional movements can be performed in the IGTS tunnels.

Material movements within first stage immobilization that are performed within the unit operations and are outside the scope of this materials transport plan except for the movement of sintered pucks on transport trays. The overhead IGTS will be used to transport trays of sintered pucks from the sintered puck inspection area to the sintered puck storage area, nondestructive examinations (NDE), and subsequently to the can loading area.

The overhead IGTS will also be used to transport rejected "green" and sintered pucks from the inspection areas to the conversion accountability measurements area. These rejected pucks will subsequently be transported to the conversion oxide crush and grind area (some will be transported to the in-process vault prior to moving to the oxide crush and grind area). The rejected pucks will be transported in containers specifically design for reject puck transport in the IGTS.

The IGTS will transport 3013 containers, standard cans, transport buckets, and transport trays between the various unit operations/glovebox lines within the conversion and ceramification areas. The following containers will be used for these material movements: 


\begin{tabular}{|l|l|}
\hline \multicolumn{1}{|c|}{ Material Type } & \multicolumn{1}{c|}{ IGTS Container } \\
\hline $\begin{array}{l}\text { All materials in 3013-type containment } \\
\text { vessels }\end{array}$ & IGTS transport cart \\
\hline Metals without 3013 containment & HYDOX basket and transport bucket assembly \\
\hline Oxide without 3013 containment & $\begin{array}{l}\text { IGTS standard can and transport bucket } \\
\text { assembly }\end{array}$ \\
\hline Sintered ceramic pucks & IGTS transport trays \\
\hline $\begin{array}{l}\text { Rejected "green" and sintered ceramic } \\
\text { pucks } \\
\text { Waste (Cut-up 3013s, etc.) }\end{array}$ & IGTS reject puck container. \\
\hline
\end{tabular}

Product flow through the IGTS tunnels is generally batch-handled in a linear serial flow pattern; however, standard can and baskets as well as product recycle requirements dictate that each IGTS transfer tunnel system be capable of bi-directional transfers. The IGTS standard cans, baskets, transport buckets and transport trays will remain within the glovebox lines and transport tunnels and will be reused. Each IGTS container will be uniquely numbered (bar code) and tracked by the IGTS. The IGTS will interface with the MC\&A computer system and provide the MC\&A system with each container's real-time location. The IGTS will transfer containers and trays on a passive cart from line to line using vertical elevators and overhead horizontal containment transfer tunnels linking the various gloveboxes. Simultaneous movements may occur within the IGTS system. Movement and transfers of containers between each IGTS transfer system will be computer controlled and will have minimal hands-on operation. In addition to servicing the process lines located on the first level of the facility, the IGTS will also transport stack feed material vertically to the facility third level.

\subsubsection{Puck Can Transport System}

Loaded puck cans will be moved from the can loading area to the puck can NDA area and later to the magazine loading/puck can storage area using an overhead puck can transport system. The puck can transport system will retrieve the puck cans from a transfer location in the puck can NDA area wall and will place the puck can in a transfer location in the magazine loading area. Equipment associated with the magazine loading area will move the puck can to a storage position or to the magazine loading position. Equipment used to move puck cans and can-in-canisters in the canister loading area are included in the System Design Description report for the area and are outside the scope of this document.

\section{Summary of PIP Material Handling Operations}

Inter-operational unit material movements required to support processing operations in the PIP Process Building will use a combination of following listed materials handling equipment: 


\begin{tabular}{|l|l|}
\hline Materials Handling Equipment & Container/Item Transported \\
\hline AGV & $\begin{array}{l}\text { Loaded standard and reusable } \\
3013 \text { containers } \\
\text { Empty reusable 3013 containers }\end{array}$ \\
\hline IGTS & $\begin{array}{l}\text { Loaded standards and reusable } \\
3013 \text { containers } \\
\text { Empty reusable 3013 containers } \\
\text { Metals in HYDOX baskets and } \\
\text { transport bucket assemblies } \\
\text { Oxides in standard can and } \\
\text { bucket assemblies } \\
\text { Sintered ceramic pucks on } \\
\text { transport trays } \\
\text { Rejected green and sintered } \\
\text { ceramic in reject puck cans }\end{array}$ \\
\hline Puck Can Transport System & $\begin{array}{l}\text { Ceramic pucks sealed in puck } \\
\text { cans }\end{array}$ \\
\hline
\end{tabular}

\subsubsection{DWPF Operations}

All material movements associated with transporting can-in-canisters to DWPF and with movement of can-in-canisters within the DWPF operations are outside the scope of this materials transport plan. These material movements are described in the System Design Description of each of the DWPF unit operations areas.

\section{3 $\mathrm{UO}_{2}$ Transport System}

$\mathrm{UO}_{2}$ will be received at the PIP south dock on commercial trucks. The material will be received in 55-gallon steel drums with the drums loaded on the truck individually or palletized with up to three drums per pallet. The $\mathrm{UO}_{2}$ drums/pallets will be unloaded from the trucks using a lift truck and will be moved into the MAA of the Process Building as quickly as practicable to reduce the time the doors through the security MAA wall are open. The pallets will be unpackaged and the drums moved one-at-a-time to the third level $\mathrm{UO}_{2}$ storage area via a freight elevator using a drum handler lift truck. Note that unloading operations must be coordinated with MC\&A to provide accountability of the $\mathrm{UO}_{2}$. A flow chart outlining the movements of $\mathrm{UO}_{2}$ is provided in Figure 2. 

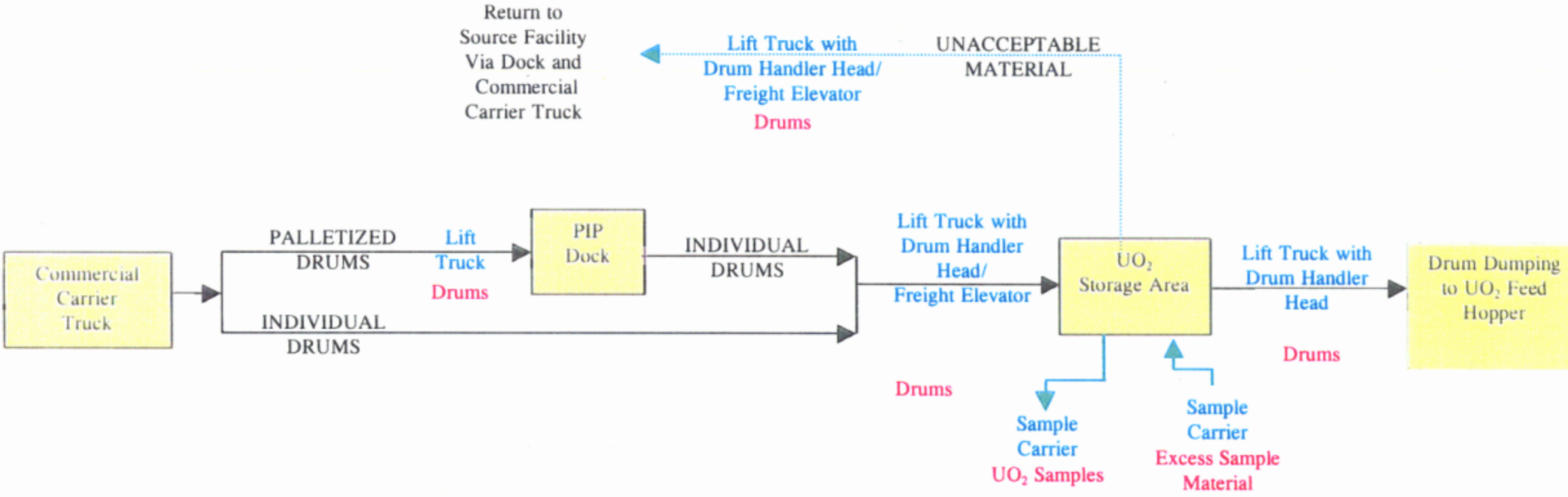

Facility

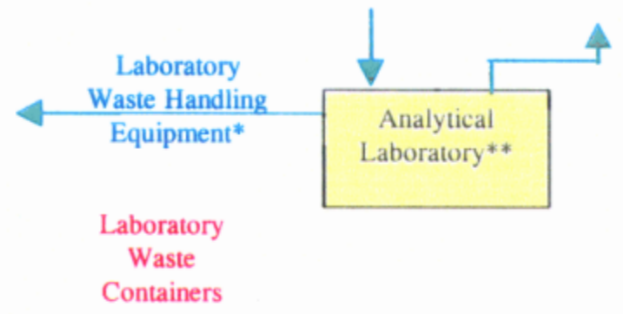

KEY

Materials Handling

Material Containment System

- Existing Equipment

** Modified/Upgraded Existing Equip.

Figure 2: Material Movements Flow Sheet for Uranium Oxide Feed Materials 


\section{Summary of $\mathrm{UO}_{2}$ Material Handling Operations}

Inter-operational unit material movements of $\mathrm{UO}_{2}$ required to support processing operations in the PIP Process Building will use a combination of the following listed materials handling equipment:

\begin{tabular}{|l|l|}
\hline \multicolumn{1}{|c|}{$\begin{array}{c}\text { Materials Handling } \\
\text { Equipment }\end{array}$} & Container/Item Transported \\
\hline Lift truck & Pallets of $\mathrm{UO}_{2}$ drums \\
\hline $\begin{array}{l}\text { Lift truck with attachable } \\
\text { drum handling head }\end{array}$ & $\mathrm{UO}_{2}$ drum \\
\hline PIP freight elevator & Lift truck with $\mathrm{UO}_{2}$ drum \\
\hline
\end{tabular}

\subsection{Non-Nuclear Feed Material, Process Consumables, and Non-Process Materials Transport System}

Items in this category will be received at a separate commodities warehouse and stored until needed for processing. The materials will be unloaded from commercial carrier trucks and stored in the warehouse using lift trucks. The materials will later be retrieved from storage and put on site trucks for transfer to the PIP. At the PIP the materials will be unloaded from the site trucks and moved to an appropriate lag storage area in the Process Building using lift trucks. A general materials flow chart for these materials is provided in Figure 3.

Details for how the materials will be distributed from lag storage will be provided later.

\section{Summary of Non-Nuclear Feed Material, Process Consumables, and Non-Process Materials Handling Operations}

Inter-operational unit material movements of non-nuclear feed material, process consumables, and non-process materials required to support processing operations in the PIP Process Building will use a combination of the following listed materials handling equipment:

\begin{tabular}{|l|l|}
\hline \multicolumn{1}{|c|}{$\begin{array}{c}\text { Materials Handling } \\
\text { Equipment }\end{array}$} & Container/Item Transported \\
\hline Lift truck & Cartons or palletized drums \\
\hline $\begin{array}{l}\text { Lift truck with attachable } \\
\text { drum handling head }\end{array}$ & Individual drums \\
\hline PIP freight elevator & $\begin{array}{l}\text { Lift truck with material drum } \\
\text { or carton }\end{array}$ \\
\hline Canister dolly & Empty canister assemblies \\
\hline
\end{tabular}

Note 1. Assumes the location for inputting the materials into the ceramification process will be on the second-level of the Process Building 


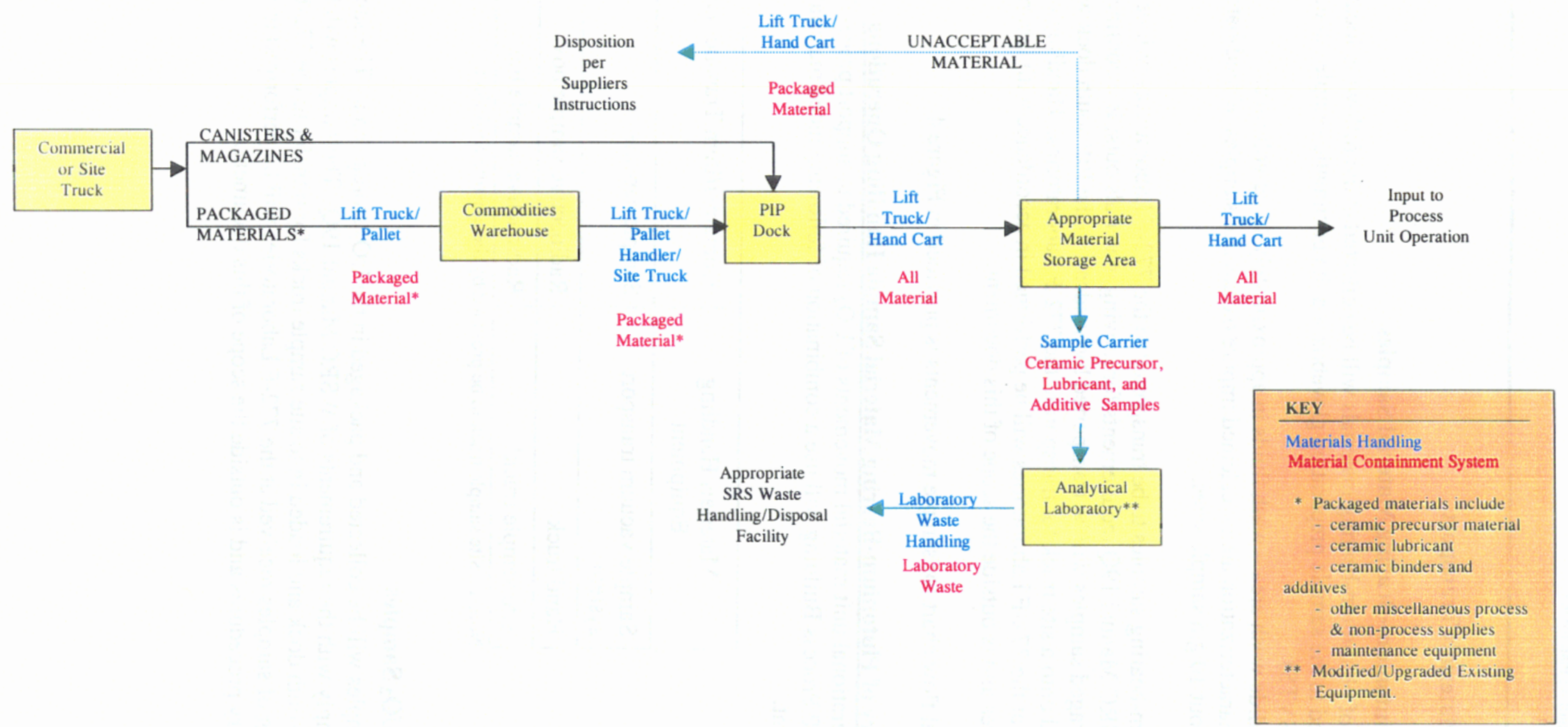

Figure 3: Material Movements Flow Sheet for Non-Nuclear Feed Materials 


\subsection{Sample Materials Transport}

\subsubsection{Plutonium-Bearing Material Samples}

Samples of plutonium-bearing materials will be collected at the following locations and transferred to the sample preparation glovebox via the pneumatic sample vacuum transport system (SVTS):

- Halide wash area - wash fluids in approximately $15 \mathrm{cc}$ volumes.

- Characterization area - calcined impure oxides and samples of feed-batched material in about 10 gm sample sizes.

Plutonium-bearing samples to be transported to the 772-F Laboratories will be packaged to meet WSRC Manual 19Q requirements for moving materials outside a confinement system. The packaged samples will be transported by handcart to the PIP south dock where they will be loaded onto a site truck for transport to the 772-F Laboratories. Handling of samples received at the $772-\mathrm{F}$ Laboratories will be performed in accordance with laboratory procedures and is outside the scope of this document.

A general flow chart for sample movements is provided in Figure 4.

\section{Summary of Plutonium-Bearing Material Sample Handling Operations} Inter-operational unit material movements of $\mathrm{UO}_{2}$ required to support processing operations in the PIP Process Building will use a combination of following listed materials handling equipment:

\begin{tabular}{|l|l|}
\hline \multicolumn{1}{|c|}{$\begin{array}{c}\text { Materials Handling } \\
\text { Equipment }\end{array}$} & Container/Item Transported \\
\hline $\begin{array}{l}\text { Sample vacuum transport } \\
\text { system }\end{array}$ & Sample capsule \\
\hline Hand truck & Radioactive sample box \\
\hline Site sample truck & Radioactive sample box \\
\hline
\end{tabular}

Note 1. Site sample truck to be provided by the existing SRS fleet.

\subsubsection{2 $\mathrm{UO}_{2}$ Samples}

$\mathrm{UO}_{2}$ samples will be collected and packaged in the $\mathrm{UO}_{2}$ storage area. The sample packages will comply with the requirements of WSRC Manual 19Q. The samples will be transported to the PIP south dock and loaded in to site sample trucks for transfer to the 772-F Laboratories. Handling of samples received at the 772-F Laboratories will be performed in accordance with laboratory procedures and is outside the scope of this document. 


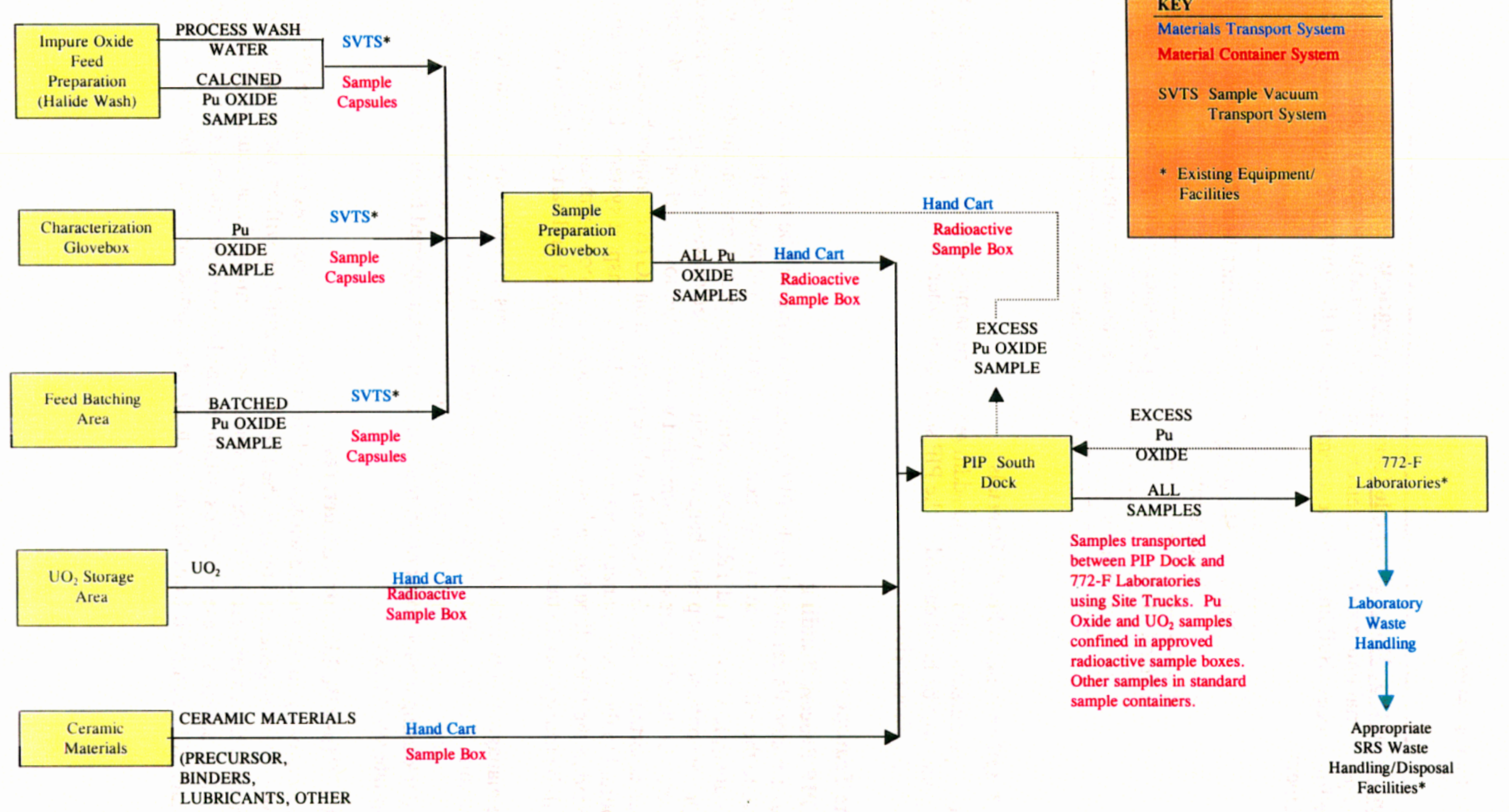

Figure 4: Material Movement Flow Sheet for Samples 


\section{Summary of $\mathrm{UO}_{2}$ Material Sample Handling Operations}

Inter-operational unit material movements of $\mathrm{UO}_{2}$ required to support processing operations in the PIP Process Building will use a combination of the following listed materials handling equipment:

\begin{tabular}{|l|l|}
\hline \multicolumn{1}{|c|}{$\begin{array}{c}\text { Materials Handling } \\
\text { Equipment }\end{array}$} & Container/Item Transported \\
\hline Hand truck & Radioactive sample box \\
\hline Site sample truck & Radioactive sample box \\
\hline
\end{tabular}

Note 1. Site sample truck to be provided by the existing SRS fleet.

\subsubsection{Other Process Feed Materials}

Ceramic precursors, lubricant, and additives will be sampled in the storage areas. Sample containers will be hand carried to the PIP south dock where they will be taken by site truck to the 772-F Laboratories.

\subsection{Waste Transport}

\subsubsection{PIP Process Building}

All waste materials generated in the PIP Process Building will be transported from their source location to the PIP or waste management area. To the extent practicable, the uncontaminated (buffer area), low-level, and TRU wastes will be segregated. Uncontaminated waste will be in appropriate containers or plastic bags and will transported to waste management areas using handcarts. In the PIP, items of contaminated waste, either low-level or TRU, sufficiently small to be transported via the IGTS system will be placed in an IGTS transport bucket and transported to the waste management area via the IGTS transport system. Larger items generated in the PIP will be bagged out of the process area confinement systems (gloveboxes) and will be transported to the waste management area using hand carts or lift truck.

Waste management will package the various waste forms in containers acceptable for disposition. These containers are typically clear plastic bags for buffer-area waste, boxes for low-level waste, and drums for TRU and mixed waste. These packages will be moved to the south dock using a hand truck or lift truck and will be transported from the facility on appropriate site trucks.

\subsubsection{Other Building and Structures}

No radioactively contaminated wastes will be generated by sources outside the PIP Process Building. Wastes generated outside the PIP Process Building will be packaged by the source generator in a manner acceptable for the waste forms (sanitary, hazardous, or mixed waste form). Movement of these materials within the facility will use handcarts or lift trucks. The materials will be shipped from the facility to the appropriate site waste facility using site trucks. 


\section{Summary of Waste Transport Operations}

Inter-operational unit material movements of waste generated in the PIP Process Building or other PIP buildings and structures will use a combination of following listed materials handling equipment:

\begin{tabular}{|l|l|}
\hline \multicolumn{1}{|c|}{$\begin{array}{c}\text { Materials Handling } \\
\text { Equipment }\end{array}$} & Container/Item Transported \\
\hline Hand truck/cart & $\begin{array}{l}\text { Light-weight boxed sanitary } \\
\text { waste }\end{array}$ \\
\hline Lift truck $^{1,2}$ & $\begin{array}{l}\text { Boxed sanitary, low-level, } \\
\text { mixed, and hazardous waste }\end{array}$ \\
\hline $\begin{array}{l}\text { Lift truck } \\
\text { handler head }\end{array}$ & Drummed waste \\
\hline Site truck & \\
\hline
\end{tabular}

Note 1. May be same lift truck with attachable drum handler head.

Note 2. Lift truck may require shielding to protect operator from radiological exposures.

Note 3. Site truck to be provided by the existing SRS fleet.

\subsection{Summary of Equipment}

The following list provides a summary of equipment needed to support materials transportation needs in the PIP.

\begin{tabular}{|c|c|l|}
\hline \multicolumn{1}{|c|}{ Equipment Item } & Qty & \multicolumn{1}{c|}{ Comment } \\
\hline $\begin{array}{l}\text { Feed Material Receiving } \\
\text { and Storage }\end{array}$ & 1 & $\begin{array}{l}\text { May require shielding } \\
\text { Drum handling head required } \\
\text { CRT handling head required }\end{array}$ \\
\hline Lift truck & 1 & $\begin{array}{l}\text { One AGV should be sufficient to support } \\
\text { PIP operations. A spare could be needed } \\
\text { to assure Uninterruptible storage retrieval } \\
\text { operations. Description of the AGV } \\
\text { including functions and requirements will } \\
\text { be presented in the Systems Design } \\
\text { Description for the storage vault. }\end{array}$ \\
\hline AGV & 2 & $\begin{array}{l}\text { Description of the conveyors including } \\
\text { functions and requirements will be }\end{array}$ \\
\hline Conveyer & &
\end{tabular}


presented in the Systems Design

Description for the shipping package unpackaging and the accountability measurements unit operations.

\begin{tabular}{|ccc}
\hline PIP Process Building & \\
\hline IGTS & $\begin{array}{c}1 \text { System } \\
\text { (2 Subsystems) }\end{array}$ & $\begin{array}{l}\text { Requirements to be finalized during the } \\
\text { project Design Phase. }\end{array}$
\end{tabular}

Overhead tunnel

TBD

systems

Transport dollies

TBD

Standard cans

TBD

HYDOX Baskets

TBD

Transport buckets

TBD

Puck recycle cans

TBD

\begin{tabular}{lll}
\hline Puck can transport & 1 System & $\begin{array}{l}\text { System requirements to be finalized } \\
\text { during the project Design Phase. }\end{array}$ \\
\hline $\begin{array}{l}\text { Sample transport system } \\
\text { SVTS } \\
\text { Sample carts }\end{array}$ & 1 System & $\begin{array}{l}\text { System requirements to be finalized } \\
\text { during the project Design Phase. }\end{array}$ \\
\hline
\end{tabular}

\begin{tabular}{l|c|c|}
\hline Sample carts & TBD & \\
\hline Lift truck & 2 & \\
\hline
\end{tabular}

\begin{tabular}{|l|c|}
\hline Attachable drum head & 1 \\
\hline Hand trucks/carts & TBD \\
\hline All Other PIP Buildings & \\
\hline
\end{tabular}

\begin{tabular}{|l|l|}
\hline All Other PIP Buildings \\
\hline Lift truck \\
Attachable drum head
\end{tabular}




\subsection{DESIGN CONCEPTS}

\subsection{Automated Guided Vehicles}

AGVs are commercially available equipment, electrically powered unit load or lift-truck style vehicles equipped with a non-wire, non-floor path guidance system. The AGVs will be modified to receive, transport, and hand-off plutonium-bearing materials contained in containers meeting the requirements of DOE-STD-3013-96 container. Salient modifications required for the $A G V$ include:

1. Addition of fixtures for holding the 3013 containers during materials movements and for placing and retrieving 3013 containers from conveyers or IGTS and for storing and retrieving 3013 containers from storage positions.

2. Addition of an articulating closed-circuit television (CCTV) camera controllable from a remote location. This CCTV system will be used to view the area around the AGV during material movements for safeguards and seçurity purposes, to verify the AGV location, and to aid in performing material transfers between the $\mathrm{AGV}$ and other equipment.

3. Addition of a bar code reader for reading the barcodes in the 3013 containers being handled and during MC\&A storage area inventories.

The PIP AGV will interface with the conveyor from the accountability measurement area and with the IGTS system. The AGV will also interface with the storage positions of the storage vault. The AGV shall be equipped to detect when maintenance is needed, including battery charging. The self-diagnostics shall provide sufficient delay that on-going AGV operations can be completed prior to the AGV advancing to the maintenance area.

Battery charging equipment as well as other equipment required to maintain the AGV will be provided in an AGV maintenance area connected to the storage vault vestibule.

\subsection{Inter-Glovebox Transport Systems}

\subsubsection{General}

The purpose of the IGTS is to transport the specified containers, either laden with material or empty, from glovebox to glovebox as required by the process flow. The IGTS system will have two subsystems - one uncontaminated (clean) and one contaminated. The uncontaminated and contaminated IGTS subsystems are physically separated to reduce the potential for contamination of the clean system.

The clean subsystems will transport feed materials from the storage vault to the material unpackaging and sorting area. These materials will be in 3013 containers that will prevent the release of materials during the movements. Contamination of this subsystem cannot be precluded. However, the potential for the subsystem becoming contaminated is considered to be very low because of the container used during the material movements. The clean IGTS subsystem will be provided with a tunnel structure that will provide confinement in the unlikely event that the subsystem becomes contaminated.

The IGTS contaminated subsystem will transport materials between the processing areas/gloveboxes after the materials have been removed from the 3013 or reusable 3013 containers. The materials will be in IGTS standard cans, HYDOX baskets, IGTS buckets, or puck recycle cans. These containers will be provided with lids, but will not be designed as 
material confinement containers. Further, some movements of the materials in these containers will be inside the process areas/gloveboxes and contamination of the exterior surfaces of the containers will occur. Although the subsystem will be treated as contaminated, administrative procedures will be implemented during operations to maintain the subsystem as "clean" as practicable. This subsystem will be enclosed in a tunnel structure that will provide confinement for materials being transported.

The location of the IGTS in the PIP is shown in Attachment 1, Drawing L-202-2.

The designs of the two subsystems shall be the similar. Each system will have an overhead transport conveyer system that will provide for horizontal moves between the processing areas. Elevator systems will be provided at each process area for vertical movements between the process area operating level and the overhead conveyer. The conveyers and elevators in both the contaminated and uncontaminated systems will be enclosed in IGTS tunnels that will provide confinement during movements of the materials. The tunnels will also provide shielding to reduce exposure to personnel in occupied areas adjacent to the tunnels.

The IGTS drive system technology shall be of similar design throughout the facility such that all electrical controls are identical. Electrical power supplied to the IGTS shall be a singlephase dedicated feed. The IGTS equipment will provide any electrical noise suppression required by the control electronics.

The IGTS shall be an integrated transport system composed of modified commercially available subsystems. The IGTS will include:

1. An overhead transfer system including a stainless steel tunnel enclosure , 8- to 10-feet above floor level, and horizontally connected to the various processing or storage areas

2. An elevator and airlock system for transferring materials vertically from the glovebox lines to the overhead horizontal transfer system. The elevator/airlock system must interface with the various glovebox lines and with the overhead transfer system during material transfers.

3. An elevator and airlock system for transferring materials vertically from the in-process vault to the overhead horizontal transfer system. The elevator/airlock system must interface with the in-process vault stacker/retriever and with the overhead transfer system during material transfers for transferring materials into, or out of, the in-process vault.

4. A method for transferring materials between various legs of the overhead, horizontal transfer system.

5. A custom gripper or carrier capable of carrying materials in $3013 \mathrm{~s}$, standard cans, or transport buckets) and capable of maintaining the containers in an acceptable orientation; i.e., prevent tipping of containers and spillage of contents. A common carrier to handle all container types may need to be developed. Gripperless, totally "hands off" transfers between IGTS subsystems are possible using a common carrier approach.

6. Software controls to integrate motion within and between each subsystem and to act as a traffic controller and real time tracker for payload carriers to support MC\&A and nuclear safety (criticality prevention) as well as processing operations.

7. Specific requirements within each glovebox that may require some unique design for that one glovebox line. For example, one line may require an offset drive system due to 
delicate product state (green pucks). However, these specific line requirements should not require a differing technology for making transfers between glovebox lines.

8. CCTV remote viewing at critical points in the transport process such as intersections where transfers are made and payload loading/unloading points. Continuous monitoring is not required.

The IGTS drive system technology shall be of similar design throughout the facility such that all electrical controls are identical. Electrical power supplied to the IGTS shall be a singlephase dedicated feed. The IGTS equipment will provide any electrical noise suppression required by the control electronics.

\subsubsection{IGTS Subsystems}

\subsubsection{Propulsion/Drive System}

The IGTS drive subsystem shall be an integrated system composed of commercially available components that may have specific modifications to facilitate their use in the PIP IGTS. To the extent practicable, the propulsion system shall have the following features:

1. The drive system should be located outside the confinement barrier to allow maintenance to be performed on uncontaminated equipment.

2. The drive mechanism should be simple and easily repaired, or replaced, to minimize time maintenance workers are exposed to radiation from the process areas.

3. The system should be automated and controlled from a remote location to reduce exposure to operations personnel.

4. The system shall allow real time tracking of payloads to support MC\&A and nuclear safety needs.

Linear synchronous motors are proposed as the material transport technology to use for the IGTS propulsion system. Linear motors are flat and oblong non-rotating electric motors that provide direct linear motion (thrust) without mechanical linkages such as ball screws. The motors referred to, as the "primary" would be installed directly on top of the transport tunnel. A "secondary" which is a stainless steel cart with permanent magnets mounted under the cart travels along the floor or under the top of the tunnel. The same forces of electromagnetism that produce torque in a rotary motor are used to produce direct linear force in linear motors. When voltage is applied to the primary linear synchronous motors a travelling magnetic wave is created which pulls the cart along the transport tunnel. Non-magnetic materials such as the stainless steel glovebox and tunnel walls can be placed between the primary and secondary while still retaining the desired action of the secondary moving in response to the current flow in the primary. Gaps in the linear motor drive system may be required due to glovebox flanges, air lock doors, etc. However, relatively small gaps of a few inches can be accommodated with this technology.

Commercial and DOE systems exist based on linear synchronous motor technology that will meet the payload and throughput requirements of this facility while keeping major drive components and complex equipment outside the containment enclosures (only a passive cart is located inside the containment enclosure). This design will minimize maintenance and reduce personnel exposure adhering to the ALARA principle. The drive components are 
modular, low profile, and generally length independent, so linear synchronous motor technology can be utilized for all IGTS subsystems within the facility. Commercially available conveyor technology could be substituted for the linear motor concept, but is less desirable due to the larger footprint of conveyor equipment within the gloveboxes. In addition, conveyors are considered to be less desirable due to the maintenance complexity of conveyors that could result in higher exposures to maintenance personnel.

\subsubsection{Glovebox Elevator Stations}

The glovebox elevator stations provide the interfaces between the overhead transport system and the glovebox operations. The elevator lifting unit consists of a pair of parallel lifting tines that fit under the lower flanges on the transport bucket. Each lift tine has two tapered dowels that engage holes on the transport bucket and provide a positive payload location without using an actuated gripper. The lift tines are mechanically connected to a back plate that also has a lead screw supernut mounted on it. The back plate is guided by $\mathrm{V}$-wheels and matching vertical track on one sided of the elevator and by flat rollers on the other side. Four V-wheels (two upper and two lower) are arranged such that the track is captured between the wheels. An identical arrangement is provided for the flat rollers.

When receiving materials from the transport system, the tines of the platen lift the transport cart and the cart is moved to a position where it will not interfere with the lowering of the transport bucket. The transport bucket is lowered to the glovebox work level where it is placed on a cart that moved the bucket through an airlock into the glovebox. The glovebox cart and the airlock are provided by the glovebox system and are out side the scope of the materials transport system.

The elevator lift is propelled vertically using a lead screw. The upper end of the lead screw is attached to a magnet (inner magnet). A second magnet (outer magnet) is attached to the drive motor and is located outside the confinement system and directly above the magnet attached to the lead screw. During operations in the elevator, the drive motor turns the outer magnet and the coupling of the fields of the two magnets cause the inner magnet and the attached lead screw to rotate thus raising of lowering the platen depending on the direction of rotation. (See Reference 2)

\subsubsection{Overhead Transport Conveyer System}

The overhead transport conveyor system provides for horizontal moves of materials between the processing areas in the PIP. Major subsystems include a transport cart, the propulsion system, and the tunnel confinement system.

\subsection{Overhead Transport Cart}

An overhead transport cart is composed of the following major items, Figure 5:

- A boxed C-section carrier frame

- Wheels

- Magnet 


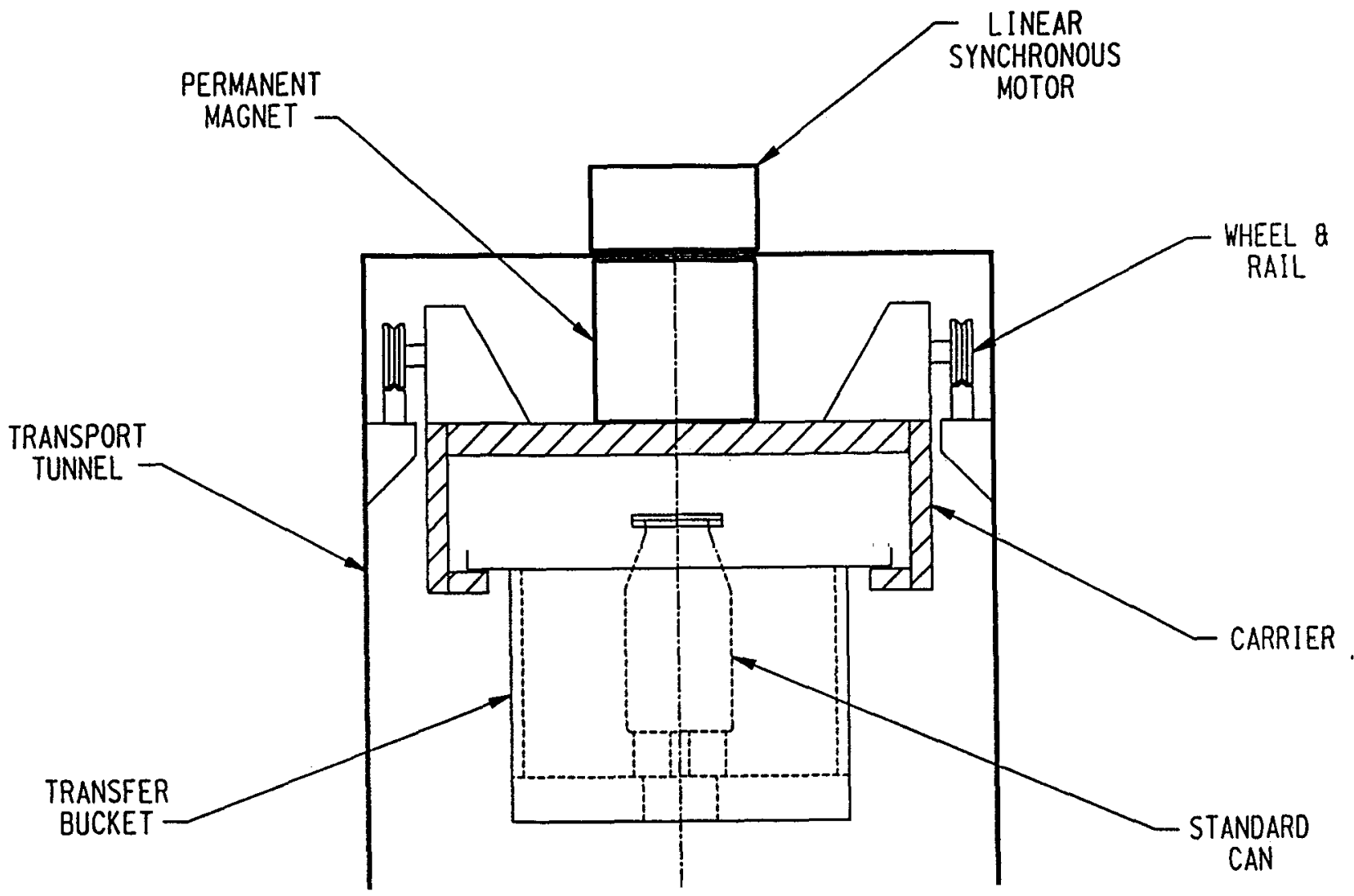

Figure 5: Schematic of Overhead Transport System Cart

The boxed C-section is oriented such that the opening in the "c" faces downward. The opening in the "c" section is sized to slide beneath flanges on the transport buckets. During operations, an elevator system will raise the transport bucket to the overhead transport elevation. The transport cart will be moved such that the lips on the $\mathrm{C}$-section are positioned under the flanges on the transport cart. The elevator system then lowers the transport bucket until it is suspended in the C-section. The elevator then continues to be lowered until it no longer obstructs movements of the transport bucket. (Refer to Reference 2)

$\mathrm{V}$-wheels are attached to the upper sides of the C-section and engage rails that run between the glovebox elevator stations. These wheels and $\mathrm{C}$-section form a cart that carries the payload between the glovebox elevator stations.

A permanent magnetic is attached to the top of the cart C-section. During movements, this magnetic couples with the magnetic field of the linear motor and pulls the cart along the rail system. 


\subsubsection{Transport Rails}

The transport rails are attached to the transport tunnel inside walls structure and provide structural support and guide the transport cart during material movements. The $V$-wheels of the transport cart roll on these rails as the cart is moved between glovebox elevator stations.

\subsubsection{IGTS Control Systems}

Distributive Control DC stepper motor operated in an open loop fashion using commercial indexer/drives are used in both the overhead and elevator mechanical drives. Each independent drive allows concurrent cart and elevator moves. All stop points are programmable, with all position being referenced from a known "home" position. Position or velocity control may be used with these controllers but for this application, standard trapezoidal velocity move profiles are used for position control. Each motor controller is interfaced via "daisy chain" RS232 communication link to a computer. The operator will have he ability to perform the following functions:

- "Home" each system (search for zero position sensor

- execute pre-programmable moves via soft buttons

a download and retrieve sequences resident within each motor controller

- manually move each system and chance velocities for each system

- graphically show cart and elevator positions when within manual move screen

a emergency stop all movements.

"Traffic controller" software will be provided to coordinate motion between all system resources (carts, elevators, etc.) based on operator material movement requests.

The overhead transport conveyer and the elevator systems each used stepper motor technology to move the payloads and to locate the payloads in position for transfers between the transport subsystems. (Reference 2)

\subsection{IGTS Functional Control Description}

The control system for the IGTS systems will be computer based. The computer system will be a tiered system consisting of:

Materials Transport Main Control Computer - Computer used for over all control of the IGTS system. Primary control of this computer will be from the metal conversion and material handling control room with supervisory control from the facility main control room. This computer will provide real time control of all material movements within the IGTS and the individual operational units.

IGTS Inter-Glovebox Tunnel Conveyance Computers - Each major segment of the IGTS tunnel system will have a separate computer. These computers/PLCs will be used to control the operation of the motor propulsion system in that segment of the tunnel system it is assigned. Primary control for these computers/PLCs will be from terminals located in the local control rooms associated with the unit operations the IGTS is supporting. Supervisor control with capability for actuating "emergency stop" orders will be provided from 
terminals located in the metal conversion control room, immobilization control room, or the facility main control room.

IGTS Elevator Computers - Each IGTS elevator section used to move transport carts between the work levels of the unit area operations/gloveboxes and the overhead IGTS tunnels will also be controlled by separate computers/PLCs. Primary control for these elevator computers/PLCs will be from terminals located in the local control rooms associated with the unit operations the IGTS is supporting. Supervisor control with capability for actuating "emergency stop" orders will be provided from terminals located in the metal conversion control room, immobilization control room, and the facility main control room.

All computers in the IGTS will interface with the facility MC\&A computer via the materials transport main control computer. All material positions/locations will be logged on the MC\&A computer.

The materials transport main control computer will control and monitor all material movements in the facility including movements within the IGTS system and within the individual unit operations. The materials transport main computer will receive requests for a material transfer from:

口 the individual unit operations automatically, or

$\square$ the terminals in the local or main control rooms

口 the local terminals at the unit operations, or

口 "call and send" buttons at each glovebox.

The material transport main control computer will verify that no physical impediment ${ }^{2}$ exists and that the requested material transfer can be performed without causing a criticality in either the inter-glovebox IGTS tunnels or elevators, or the destination glovebox/location. If everything registers "as-acceptable", the main control computer will then issue the required commands to the appropriate IGTS conveyance computer. The IGTS tunnel conveyance computer will in turn issue the necessary movement commands to the tpropulsion system and a "heads up" signal (signal that a material movement involving the computer is impending) to the appropriate IGTS elevator and intra-glovebox conveyance computers/PLCs. The involved IGTS elevator computer/PLC will use the "heads-up" signal in conjunction with an in-position signal from the IGTS conveyance computer to initiate its movement control sequence. The intra-glovebox computer/PLC will use its "head-up" signal in conjunction with an in-position signal from the IGTS elevator computer/PLC to initiate its material movement sequence.

Each major segment of the IGTS system including each elevator system segment and each transport cart, will have sensors or other instrumentation located outside the confinement tunnels to detect proximity of other materials or carts being moved to assure that fissile

2. In this context, an impediment signifies an operational condition within the IGTS system segment to be used or in the source or receiving unit operation. Examples of such impediments could include detection of failed or inoperable equipment in the IGTS system or unit operations to be involved with the material movement, an on-going material movement in the tunnel segment or tunnel elevator required for the new material movement, on-going material movements in other IGTS or unit operations that could interact with the new material movement. Operations, security, health protection, MC\&A must concur with all materials movements Lack of concurrence for a material movement by any of these organizations is another source of impediments to material movements. 
materials are maintained at sufficient distances to prevent a criticality event. Each major component in the IGTS tunnel or elevator system will have sensors or other instrumentation that will alert materials transport main control computer and the appropriate IGTS tunnel conveyance or elevator computer of equipment failures or failures of the equipment to perform its intended operation. These computers in turn will bring the affected segments of the system to a safe operational mode and preclude initiation of new materials movements in the affected areas until appropriate maintenance on the equipment has been completed and the system is acceptable for operation.

Intra-Glovebox Conveyance Computers - Intra-glovebox conveyance computers/PLCs will be used to control movements of materials inside each operational unit/glovebox. These computers are outside the scope of this materials transport plan and will be described in the System Design Descriptions for the respective unit operation. These computers will control movement of materials between the respective unit operations and the IGTS. Control of transfers within the airlocks separating the IGTS and the unit operations will be controlled by these computers/PLCs.

\subsubsection{IGTS Confinement Subsystems}

The IGTS will include a network of transport tunnels interconnecting the various PIP operational units. These tunnels will enclose both the overhead transport system and the glovebox elevator stations. The tunnels will provide both structural support for the conveyance systems and confinement for the plutonium-bearing materials being transported. In addition, the tunnels will inhibit theft or diversion of the materials. The tunnel structures will also provide shielding to reduce radiological exposures to workers in the facility. They will be provided with ventilation with airflow into the contaminated exhaust system. The IGTS will be separated from the gloveboxes by airlocks or the ventilation flow will be from the IGTS into the gloveboxes. Pressures in the IGTS tunnels will be negative to the surrounding occupied rooms.

\subsubsection{Containers}

\section{Material Receipts and Storage}

All plutonium-bearing feed materials received by the PIP shall be in DOE-STD-3013-96 storage containers packaged in DOE approved shipping packages.

\section{Metals and Alloys}

Metals and alloys will be transported in an HYDOX Basket and bucket assembly, Figure 6. The metals and alloys will be placed in the basket portion of the assembly and the basket will be enclosed in an IGTS Transport bucket during all IGTS material movements. The basket is designed for insertion into the HYDOX reaction chamber in the metal conversion area. The shell of the basket is perforated to allow hydrogen to enter and react with the plutonium in the metals. The design will also allow plutonium hydride from the chemical reaction to fall from the basket for collection in the reaction chamber. 


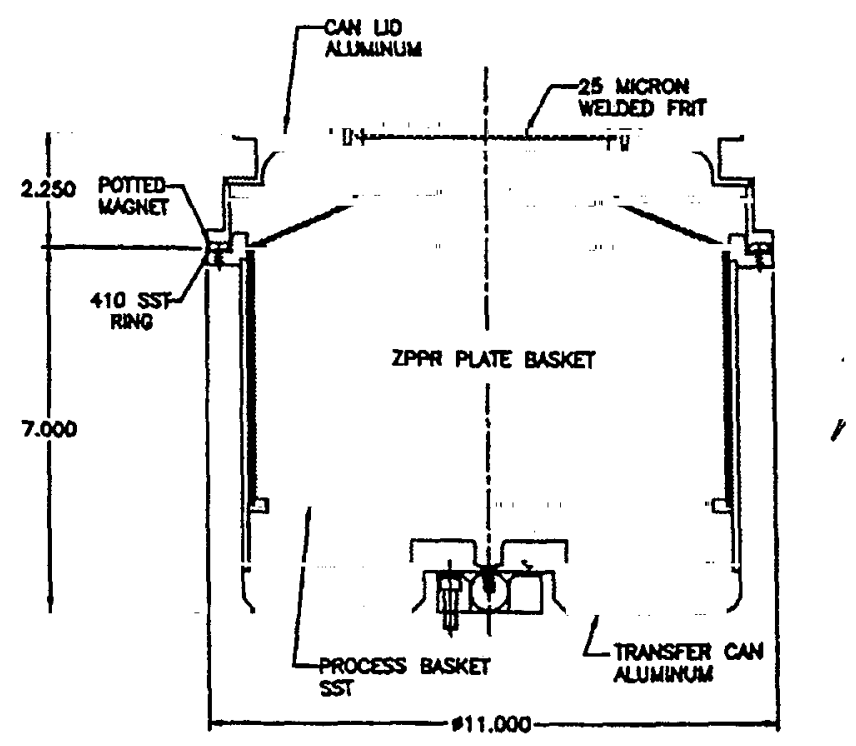

Note: External lifting flanges not shown.

Figure 6: Sketch of Prototype HYDOX Basket and Bucket Assembly

During materials movements in the IGTS, the HYDOX baskets are enclosed in an IGTS transport bucket. The bucket will have a lid that will enclose the basket and materials inside the bucket. The bucket design will support the HYDOX baskets during material movements to mate with the IGTS transport carts. The bucket, in combination with the transport cart, has features to prevent the bucket and basket assembly from toppling or falling off the transport cart and spilling the materials.

\section{Oxides}

Oxides will be transported in an IGTS standard container and bucket assembly, Figure 7. The oxide will be placed in the standard can portion of the assembly. The standard container is provided with an attachable lid to keep the oxide inside the container. The container design will allow the various PIP conversion unit operations to remove the container from the bucket when material is transferred from the IGTS system into the confinement system for the unit operation.

During IGTS material transport movements, the standard container will be supported by the lower section of the IGTS buckets. The bucket, in combination with the transport cart, has features to prevent the bucket and standard can from toppling or falling off the transport cart and spilling the materials. 


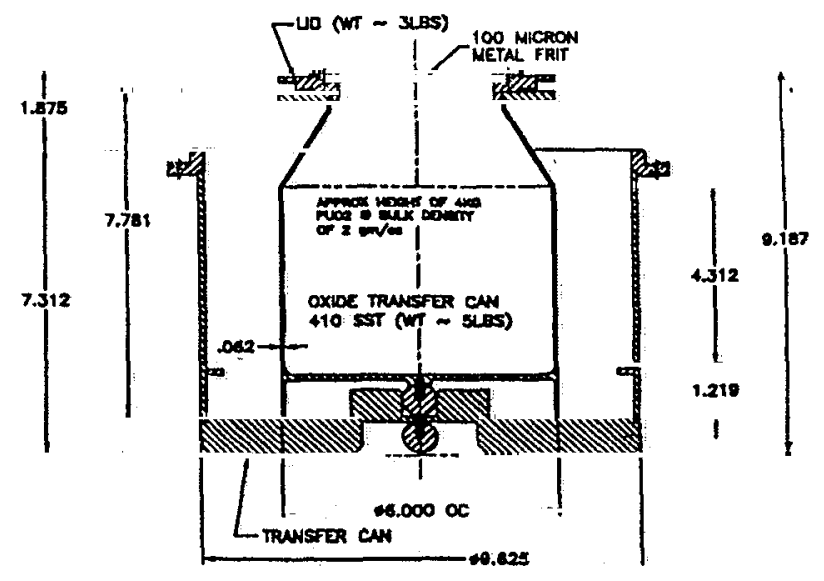

Note: External lifting flanges not shown.

Figure 7: Sketch of Standard Can and Bucket Assembly

\section{Waste and Miscellaneous Items}

Small volumes of waste materials and miscellaneous items, mainly hand tools, will be

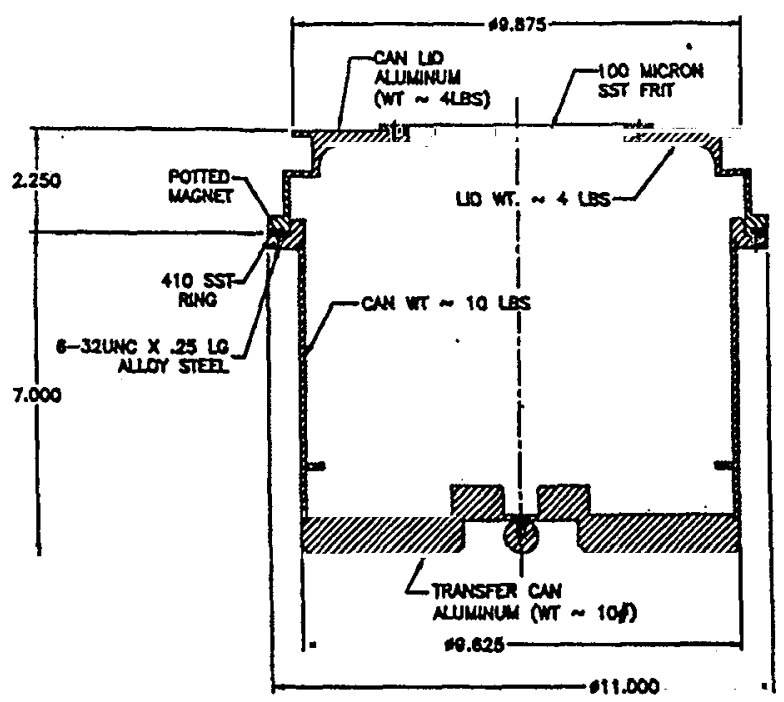

transported in IGTS transport buckets, Figure 8. These buckets are the same as those used for Note: External lifting flanges not shown.

Figure 8: Sketch of Prototype IGTS Transport Bucket 
carrying HYDOX baskets and Standard cans and have been designed to mate with the IGTS transport carts.

\section{Reject Pucks}

Rejected "green" and sintered pucks will be transported in container assemblies similar to the design described previously for oxides. The reject puck transport container will have an upper section taper design similar to the standard can. However, the angle of the taper will be modified to facilitate dumping of the rejected pucks from the container.

\section{Acceptable Sintered Pucks}

The sintered puck transport trays will be used to transport sintered pucks from the sintered puck weigh/inspect operational unit to sintered puck storage and puck NDA/NDE and subsequently to the puck can loading area. Conceptually, metal trays will be used to carry the pucks. These metal trays will also be designed to mate with the IGTS transport carts and will have features to prevent puck falling off the trays during movements.

\subsubsection{IGTS Confinement Concept}

Three levels of confinement will be provided between the IGTS systems and the exterior of the PIP process building. Although the IGST standard can and the HYDOX basket/bucket assembly designs used in the IGTS provide lids for inhibiting the migration of plutoniumbearing materials from the containers. The containers are not confinement barriers. The primary confinement barrier for the IGTS will be the IGTS tunnel structures. The HVAC system for the PIP will be designed to maintain the pressure inside the tunnels negative with respect to the exterior to the tunnels and positive to the gloveboxes it connects to.

Secondary and tertiary confinement will be provided by other design features of the PIP process building and are not part of the materials transport system. Secondary confinement will be provided by the walls, floors, and ceilings of the PIP rooms and hallways through which the IGTS tunnels pass. Tertiary confinement will be provided by the exterior structure of the PIP Process Building and the HEPA filters in the ventilation exhaust system. Airlocks are provided at the secondary and tertiary confinement boundaries.

\subsubsection{Sample Vacuum Transport System}

The plutonium-bearing samples will be transported to the sample preparation glovebox using a pneumatic sample vacuum transport system. The system will be vacuum based and will basically propel a sample capsule through a system of double walled tubing from the gloveboxes where samples are taken to the sample preparation glovebox where some analyses may be done. The majority of the capsules will be prepared for transfer out of the PIP to the $772-\mathrm{F}$ laboratory.

Within the PIP, double wall stainless steel or PVC tubing will be used to serve as the transport corridor. The number of bends and couplings shall be minimized and with the bend radius not less than three feet. A custom designed loader/receiver shall be installed on both ends of the transport tube and therefore shall be installed in each glovebox where samples are taken. A HEPA filter is required on the suction/exhaust of each loader/receiver station. A control station with programmable logic controller will be installed at each glovebox where samples are sent or received. The control station will consist of basically a system 'on' switch, a 
'send' switch, a 'send' light, a 'receive' light, and a light to signal the presence of a sample in the loader/receiver. The control components will be mounted in a 6" $\times 6$ " $\times 4$ " deep stainless steel enclosure. Other components are solenoid valves, a centrifugal blower to generate the suction required to transport the sample capsules and a cabinet to mount the blower, tubing, valving and wiring.

\subsection{Puck Can Transport System}

The puck can transport system will transport loaded puck cans from the (puck can) product NDA area to the magazine loading area. The loaded puck cans will be nominally $7.6 \mathrm{~cm}(3-$ inches) in diameter by 20 -inches long and will weigh about $50-\mathrm{kg}$ ( $23 \mathrm{lbs})$. The puck cans are hermetically sealed; thus, the system can be operated as an uncontaminated system. Conceptually, this transport system will be similar to the IGTS modified to transport the puck cans. Alternately, commercial conveyor-type technology can be used.

\subsection{Lift Truck}

Lift trucks shall be a commercially available design. Lift trucks used to unload material receipts delivered in SSTs shall be modified as required by the DOE Albuquerque Operations Office. These modifications typically require limiting the maximum lift truck mast height and. the maximum travel speed.

\subsection{Hand Trucks/Carts}

The hand truck/carts shall be a commercially available design.

\subsection{Freight Elevator}

The freight elevators shall be of commercially available design and sized during the design phase. The design criteria will include the capability to transport the PIP lift truck (including operator) carrying a fully loaded $\mathrm{UO}_{2}$ drum (nominally $4400 \mathrm{~kg}$ (2000 lbs) per drum).

\subsection{Personnel Elevators}

Personnel elevators shall be of commercially available design and sized during the Design Phase.

\subsection{FUNCTIONAL PERFORMENACE}

\subsection{Functional Classifications}

Functional classifications of SSCs in the materials transport systems shall be determined using the procedures defined in WSRC Manual E7, Procedure 2.25, Functional Classifications, or equivalent procedure, during the design phase.

HOLD During the conceptual design phase, the functional classifications are tentatively identified for general SSCs in the materials handling systems:

Safety Class No materials transport SSCs were identified as performing a safety class function.

Safety-Significant Tunnel structures and shells for the inter-glovebox transport system (Provides the primary confinement barrier for plutoniumbearing materials being moved between gloveboxes where the 
materials are not confined by a containment vessel such as a 3013)

Production Support Portions of the inter-glovebox transport system not identified as safety-significant, puck can transport system, AGVs, lift trucks, freight elevator, and intra-unit operations equipment

General Service Hand trucks and carts

\subsection{Functional Performance Requirements}

\subsubsection{Facility-Wide Functional Performance Requirements}

F5.2.1.1 The materials transport systems shall move materials described in the following list. The materials, with the exception of some maintenance items, being transported during each movement will be containerized. Items being transported, containers used, and the equipment planned for moving the materials are listed in Table I.

\section{- Process feed materials}

- Plutonium-bearing feed materials

- Clean metal. Pure plutonium metal generally with less than 100 parts per million of any given chemical impurity. The plutonium metals can be either weapons-grade or non-weapons-grade. The metal may have some oxidation or reduction residues (primarily calcium and magnesium) on the surface. The only major chemical impurities are gallium and radioactive decay products such as americium, neptunium, and uranium. Examples of pure metal items include unalloyed "buttons" of plutonium metal, billets, ingots, castings or rough machined items, finished machined weapons components, and other miscellaneous small metal pieces and parts. It is assumed that all metal will have been recast, if necessary, to destroy any classification of the pieces of metal.

- Clean oxide. This category contains oxidized plutonium with the plutonium content being equal or less than 85 weight percent. This means that there are up to 3 weight percent metallic impurities.

- Impure oxide. These plutonium oxides are mixed with between 3 and 50 weight percent impurities. This category includes oxides mixed with potassium chloride.

- Uranium/plutonium oxide. This category contains plutonium oxide mixed with enriched uranium oxide. This category may run from uranium oxide slightly contaminated with plutonium to plutonium oxide slightly contaminated with uranium.

- Recycled pucks. Process pucks, including both unsintered ("green") and sintered pucks judged to be unacceptable for input to the second stage immobilization processing.

- Uranium oxide Depleted uranium oxide $\left(\mathrm{UO}_{2}\right)$ will be procured from a commercial supplier.

- Other process feed materials

- Ceramic precursor

a Ceramic additives

- Ceramic lubricant

\section{- Process consumables}

- DWPF canisters with internal racks 
- Magazines

- Puck cans and lids

- Process support equipment and materials

- Materials transport buckets, standard cans, HYDOX baskets

- Sample containers

- Empty reusable 3013 containers

- Bottled gases - helium, argon

- Liquid nitrogen dewars

- Recycle materials/equipment

- Waste

- Non-process materials

- Maintenance equipment

F5.2.1.2 The material movement capacity of the transport systems shall be capable of delivering materials to, and between, all unit-operations at a rate sufficient to meet production needs and not cause production delays in the unit-operations. The nuclear safety (criticality prevention) and materials control and accountability requirements will impose other constraints on the movement of fissile materials in the plant.

R5.2.1.2a The design basis for movements of plutonium-bearing materials in the PIP shall be as indicated in Table $I$ and is based on the material flow diagram for the PIP, Figures 1-A and B. (Note: Table I assumes that material movements in DWPF for unit-operations including the glass filled can-in-canisters from the melt cell through storage in the Glass Waste Storage Building will be performed per existing DWPF procedures and are also outside the scope of this document. The PIP project is responsible for modifications to the DWPF dock and to DWPF transfer airlock materials handling equipment to provide for receiving can-in-canisters and moving them into the DWPF melt cell. Additional information regarding the DWPF modifications is provided in the System Design Description report (to be written).)

F5.2.1.3 The materials transport systems shall provide the containers for the movement of materials in each system.

R5.2.1.3a The containers shall comply with the requirements of:

- Document SMP 99-014, Reference 3

- Design Performance Requirements for the HYDOX basket (To be written)

- Design Performance Requirements for standard metal transfer bucket (To be written)

- Design Performance Requirements for standard recycle puck transfer container (To be written)

R5.2.1.3b The materials handling systems will not have provisions for transferring materials between material transport containers/cans or for transferring materials between the material transport cans and equipment associated with the unit operations. 
R5.2.1.3c The various unit operations areas shall be responsible for transferring materials between the materials cans and the process equipment and for preparing the cans/containers and their contents for movement within the materials transport systems.

F5.2.1.4 Structural design of materials transport sub systems including attachments of the materials handling systems to building structures shall be seismically designed.

F5.2.1.4a Structural design of the materials transport systems shall comply with the requirements of WSRC-TM-95-1, Engineering Standards Manual, Standard 01060, and shall be NRC Compliant.

F5.2.1.4b As a minimum, the structural design of materials transport system subsystems shall comply with the requirements of the Uniform Building Code (UBC).

\begin{tabular}{|c|c|c|c|c|c|c|}
\hline \multicolumn{7}{|c|}{$\begin{array}{l}\text { Table I } \\
\text { erational Movement Rate Requirements } \\
\text { rocess Feed Materials }\end{array}$} \\
\hline \multirow{2}{*}{\multicolumn{2}{|c|}{ Movement Origin and Destination }} & \multirow{2}{*}{$\begin{array}{l}\text { Material/ } \\
\text { Container }\end{array}$} & \multirow{2}{*}{$\begin{array}{c}\text { Estimated } \\
\text { Weigh, lbs, Per } \\
\text { Transfer }\end{array}$} & \multicolumn{2}{|c|}{ Rate } & \multirow{2}{*}{ Equipment } \\
\hline & & & & Avg. & Max. & \\
\hline \multicolumn{2}{|c|}{ Plutonium-Bearing Materials } & & & & & \\
\hline \multirow{6}{*}{$\begin{array}{l}\text { Feed } \\
\text { Material } \\
\text { Receiving } \\
\text { and Storage } \\
\text { Operations }\end{array}$} & $\begin{array}{l}\text { Off-load trucks and move to } \\
\text { staging area* }\end{array}$ & $\begin{array}{c}\text { Shipping } \\
\text { package/CRT }\end{array}$ & & & & Lift truck \\
\hline & $\begin{array}{l}\text { Staging area to shipping } \\
\text { package storage area* }\end{array}$ & Shipping package & & • & & $\begin{array}{l}\text { Lift truck with } \\
\text { drum handling } \\
\text { head }\end{array}$ \\
\hline & $\begin{array}{l}\text { Shipping package storage } \\
\text { area to Confirmatory } \\
\text { Measurements Area and } \\
\text { Return }\end{array}$ & Shipping package & & & & $\begin{array}{c}\text { Lift truck with } \\
\text { drum handling } \\
\text { head }\end{array}$ \\
\hline & $\begin{array}{l}\text { Confirmatory measurements } \\
\text { area to shipping package } \\
\text { unpackaging area }\end{array}$ & Shipping package & & & & $\begin{array}{c}\text { Lift truck with } \\
\text { drum handling } \\
\text { head }\end{array}$ \\
\hline & $\begin{array}{l}\text { Shipping package storage } \\
\text { area to shipping package } \\
\text { unpackaging area* }\end{array}$ & Shipping package & & & & $\begin{array}{l}\text { Lift truck with } \\
\text { drum handling } \\
\text { head }\end{array}$ \\
\hline & $\begin{array}{l}\text { Shipping package } \\
\text { unpackaging area } \\
\text { accountability measurements } \\
\text { area* }\end{array}$ & 3013 & & & & Conveyor \\
\hline
\end{tabular}


Table I

PIP Materials Inter-Operational Movement Rate Requirements for Process Feed Materials

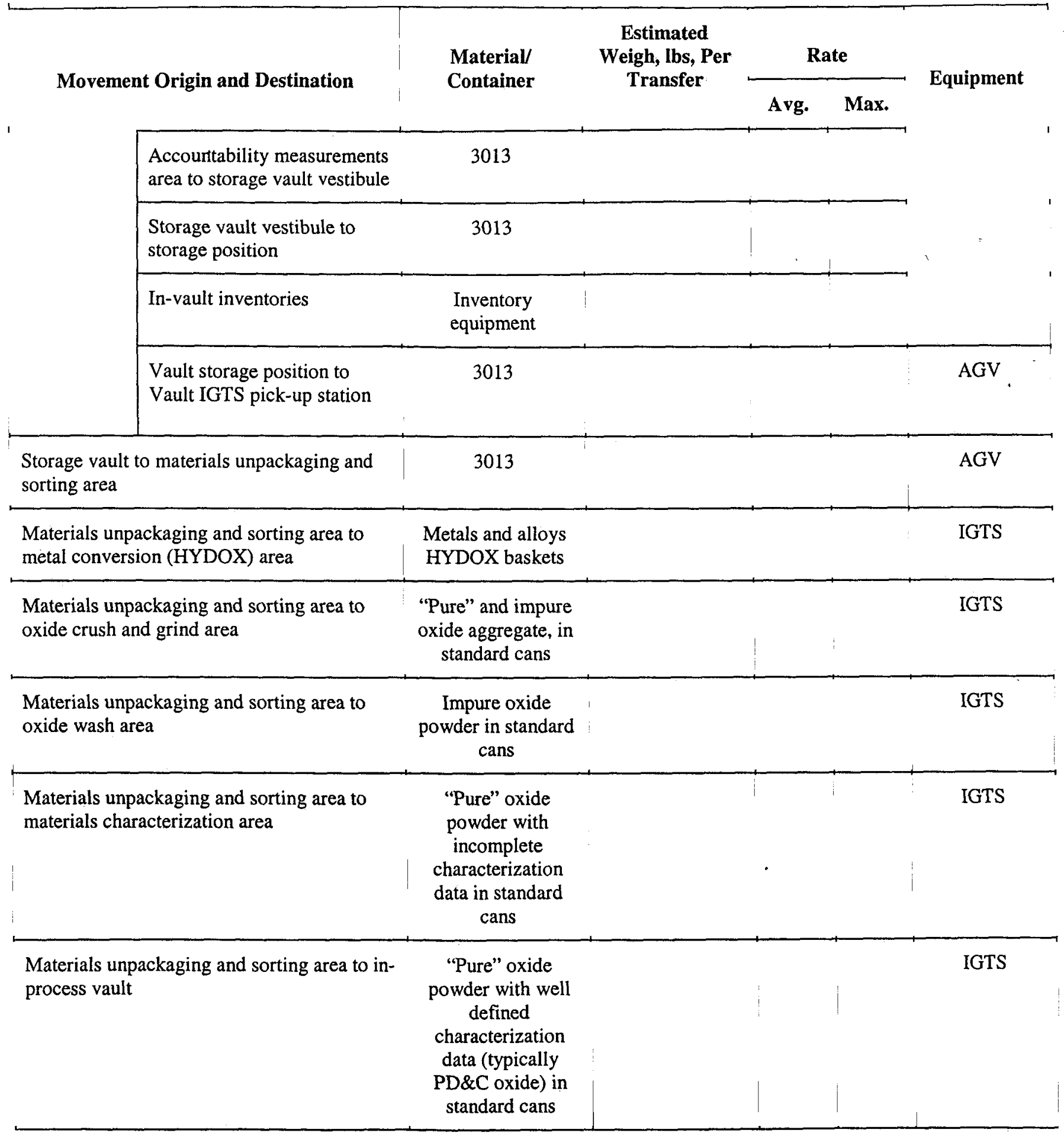




\section{Table I}

\section{PIP Materials Inter-Operational Movement Rate Requirements for Process Feed Materials}

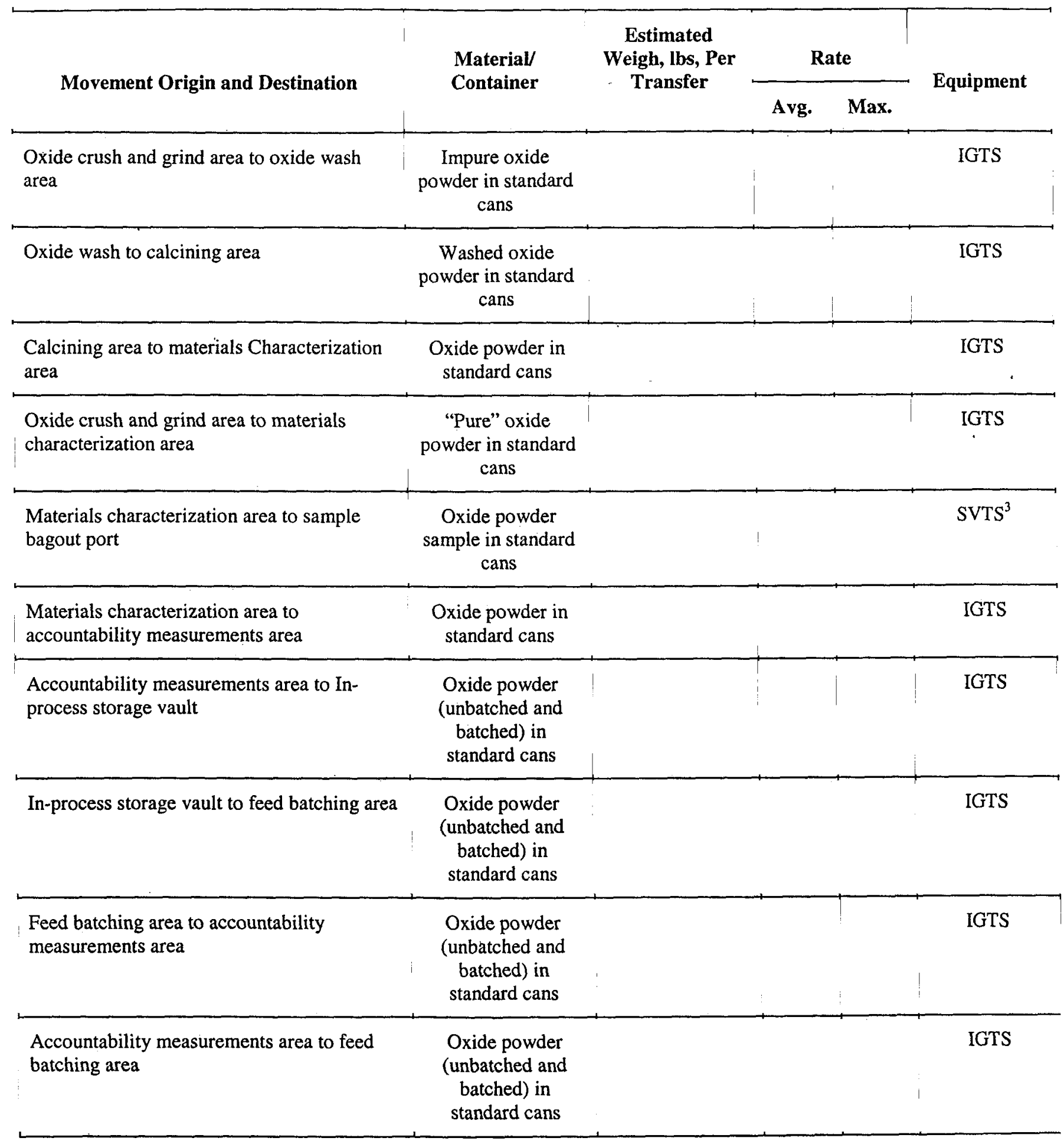


Table I

\section{PIP Materials Inter-Operational Movement Rate Requirements} for Process Feed Materials

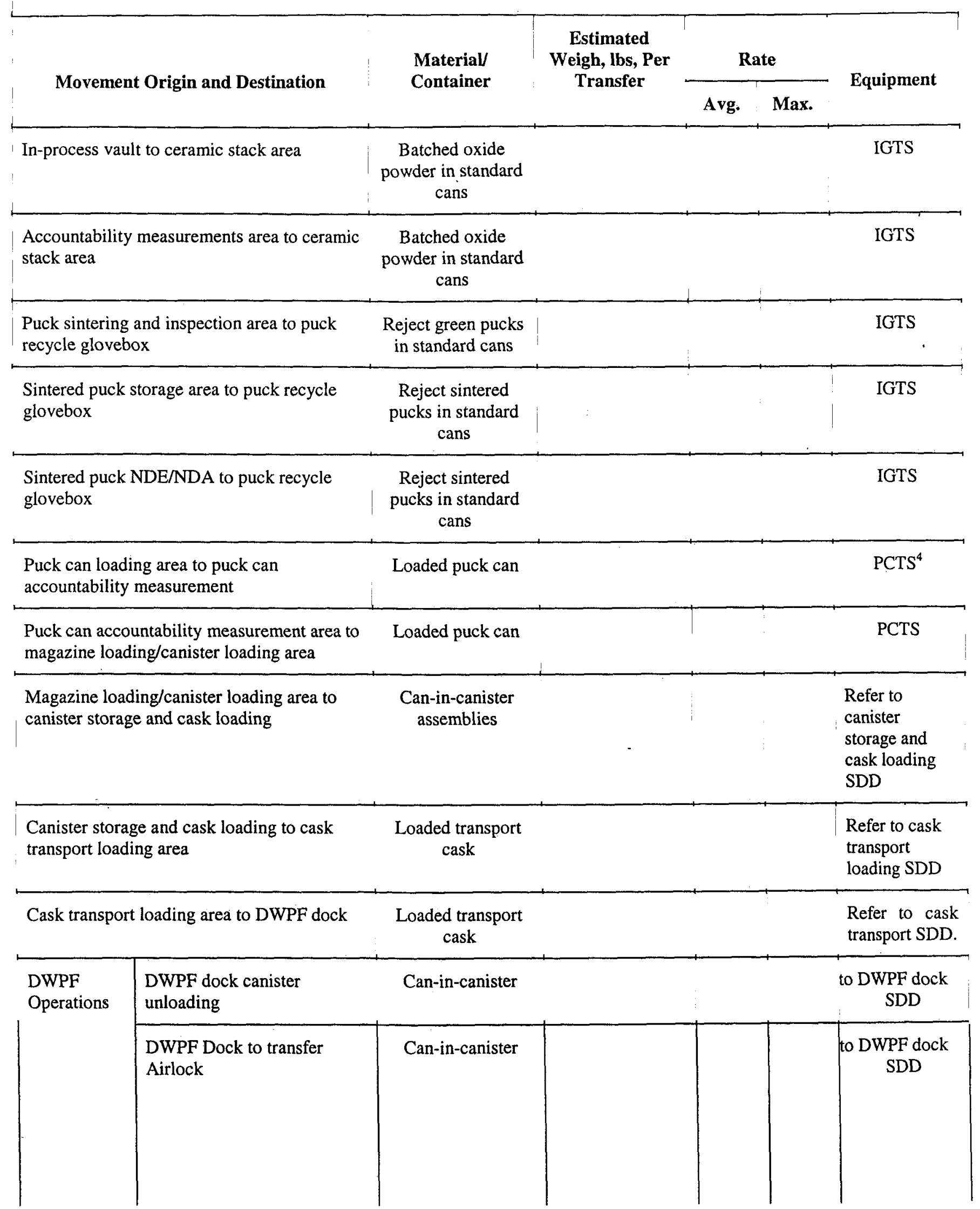




\section{Table I}

\section{PIP Materials Inter-Operational Movement Rate Requirements for Process Feed Materials}

\begin{tabular}{|c|c|c|c|c|c|}
\hline \multirow{2}{*}{ Movement Origin and Destination } & \multirow{2}{*}{$\begin{array}{l}\text { Material/ } \\
\text { Container }\end{array}$} & \multirow{2}{*}{$\begin{array}{l}\text { Estimated } \\
\text { Weigh, lbs, Per } \\
\text { Transfer }\end{array}$} & \multicolumn{2}{|c|}{ Rate } & \multirow{2}{*}{ Equipment } \\
\hline & & & Avg. & Max. & \\
\hline $\begin{array}{l}\text { Transfer airlock to melt cell } \\
\text { entry port }\end{array}$ & Can-in-canister & & & & $\begin{array}{l}\text { Refer to } \\
\text { DWPF } \\
\text { canister } \\
\text { handling SDD }\end{array}$ \\
\hline $\begin{array}{l}\text { Melt cell entry port to melt } \\
\text { cell }\end{array}$ & Can-in-canister & & & & $\begin{array}{l}\text { Refer to } \\
\text { DWPF } \\
\text { canister } \\
\text { handling SDD }\end{array}$ \\
\hline $\begin{array}{l}\text { Melt cell to glass pouring } \\
\text { area }\end{array}$ & Can-in-canister & & & & $\begin{array}{c}\text { Existing } \\
\text { overhead crane }\end{array}$ \\
\hline $\begin{array}{l}\text { Glass pouring area to canister } \\
\text { decontamination and closure } \\
\text { area }\end{array}$ & $\begin{array}{l}\text { Glass filled can-in- } \\
\text { canister }\end{array}$ & & & & $\begin{array}{c}\text { Existing } \\
\text { DWPF } \\
\text { canister dolly } \\
\text { and overhead } \\
\text { crane }\end{array}$ \\
\hline $\begin{array}{l}\text { Canister decontamination and } \\
\text { closure area to glass waste } \\
\text { storage building }\end{array}$ & $\begin{array}{l}\text { Glass filled can-in- } \\
\text { canister } \\
\end{array}$ & & & & $\begin{array}{c}\text { Existing } \\
\text { DWPF } \\
\text { canister dolly, } \\
\text { overhead crane } \\
\text { and shielded } \\
\text { canister } \\
\text { transporter }\end{array}$ \\
\hline \multicolumn{6}{|l|}{ Uranium Oxide Feed Movements } \\
\hline $\mathrm{PIP}$ dock to $\mathrm{UO}_{2}$ storage & Drums & & & & Lift truck \\
\hline $\mathrm{UO}_{2}$ storage to $772-\mathrm{F}$ & Samples & & & & $\begin{array}{l}\text { SVTS, cart, } \\
\text { site truck }\end{array}$ \\
\hline $\mathrm{UO}_{2}$ storage to ceramic stack area & Empty drums & & & & Lift truck \\
\hline Ceramic stack area to $\mathrm{UO}_{2}$ storage area & Empty drums & & & & Lift truck \\
\hline $\mathrm{UO}_{2}$ storage area to PIP dock & Drums/boxes & & & & Lift truck \\
\hline
\end{tabular}




\section{Table I}

PIP Materials Inter-Operational Movement Rate Requirements for Process Feed Materials

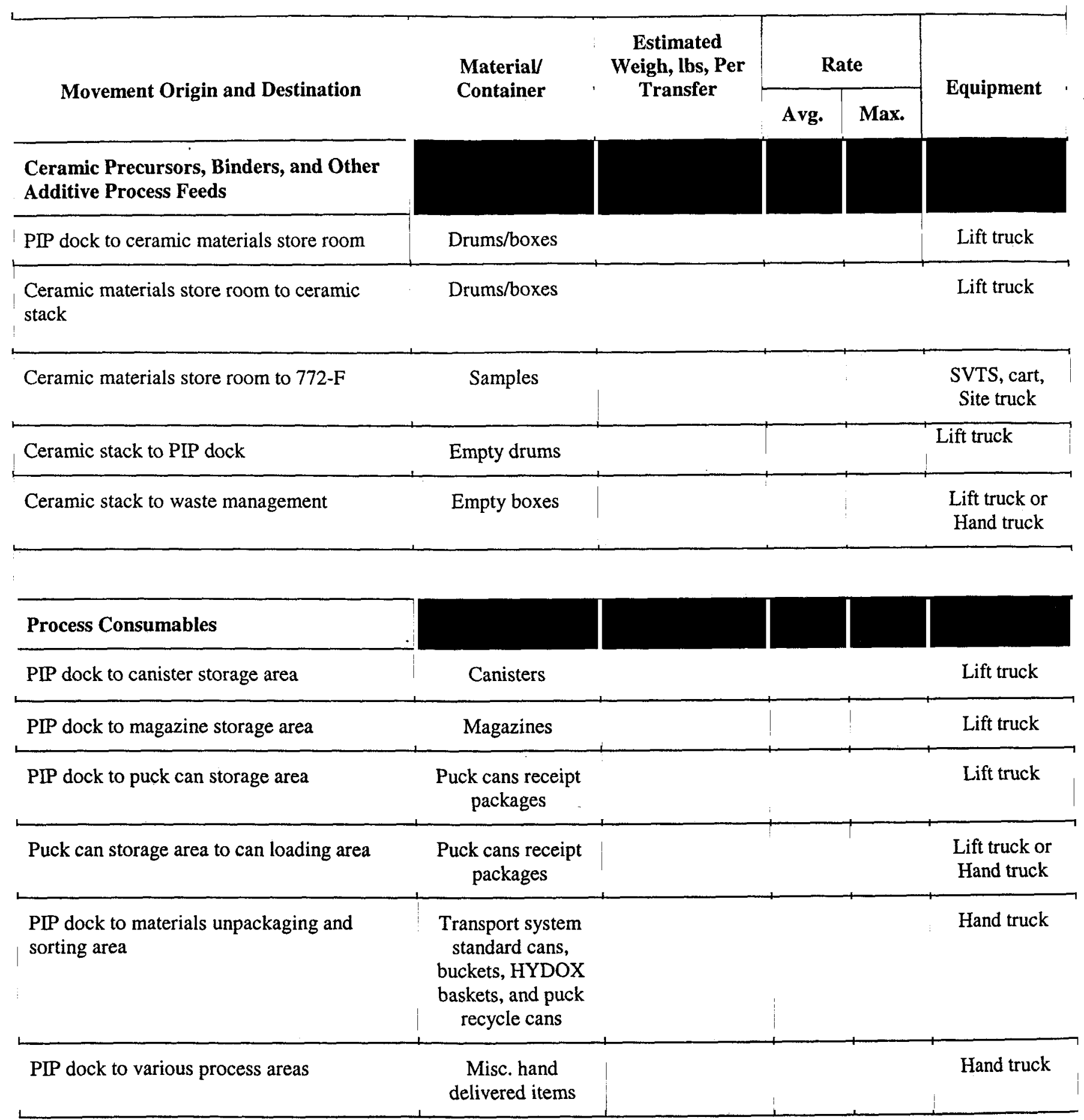




\section{Table I}

\section{PIP Materials Inter-Operational Movement Rate Requirements for Process Feed Materials}

\begin{tabular}{|c|c|c|c|c|c|}
\hline \multirow{2}{*}{ Movement Origin and Destination } & \multirow{2}{*}{$\begin{array}{l}\text { Material/ } \\
\text { Container }\end{array}$} & \multirow{2}{*}{$\begin{array}{l}\text { Estimated } \\
\text { Weigh, lbs, Per } \\
\text { Transfer }\end{array}$} & \multicolumn{2}{|c|}{ Rate } & \multirow{2}{*}{ Equipment } \\
\hline & & & Avg. & Max. & \\
\hline \multicolumn{6}{|l|}{ Non-Process Items } \\
\hline PIP to store room & Misc. supplies & & & & $\begin{array}{l}\text { Lift truck or } \\
\text { hand truck }\end{array}$ \\
\hline \multicolumn{6}{|l|}{ Waste Handling } \\
\hline $\begin{array}{l}\text { Materials unpackaging and sorting area to } \\
\text { waste handling area }\end{array}$ & Scrap 3013 parts & & & & $\begin{array}{l}\text { IGTS or hand } \\
\text { truck }\end{array}$ \\
\hline All PIP areas to waste management & $\begin{array}{l}\text { Bagged, failed } \\
\text { equipment \& misc. } \\
\text { waste }\end{array}$ & & & & $\begin{array}{l}\text { IGTS or hand } \\
\text { truck }\end{array}$ \\
\hline Waste management to PIP dock & Drums, bags, boxes & & & & $\begin{array}{l}\text { Lift truck or } \\
\text { hand truck }\end{array}$ \\
\hline \multicolumn{6}{|l|}{ Maintenance Items } \\
\hline Contaminated storage to PIP south dock & $\begin{array}{l}\text { Contaminated } \\
\text { replacement parts } \\
\text { and maintenance } \\
\text { equipment/tools }\end{array}$ & & & & $\begin{array}{l}\text { Lift truck \& } \\
\text { Site truck }\end{array}$ \\
\hline Commodities warehouse to PIP south dock & $\begin{array}{l}\text { Uncontaminated } \\
\text { replacement parts } \\
\text { and maintenance } \\
\text { equipment/tools }\end{array}$ & & & & $\begin{array}{l}\text { Lift truck \& } \\
\text { site truck }\end{array}$ \\
\hline Throughout PIP facility to PIP south dock & $\begin{array}{l}\text { Reusable parts and } \\
\text { maintenance } \\
\text { equipment/tools }\end{array}$ & & & & $\begin{array}{l}\text { Lift truck or } \\
\text { hand truck }\end{array}$ \\
\hline $\begin{array}{l}\text { Throughout PIP facility to instrument repair } \\
\text { areas (contaminated and uncontaminated } \\
\text { instrument repair areas) }\end{array}$ & $\begin{array}{l}\text { Repairable } \\
\text { instruments }\end{array}$ & & & & $\begin{array}{l}\text { Lift truck or } \\
\text { hand truck }\end{array}$ \\
\hline $\begin{array}{l}\text { Throughout PIP facility to mechanical } \\
\text { equipment repair area (contaminated and } \\
\text { uncontaminated repair areas) }\end{array}$ & $\begin{array}{l}\text { Repairable } \\
\text { equipment }\end{array}$ & & & & $\begin{array}{l}\text { Lift truck or } \\
\text { hand truck }\end{array}$ \\
\hline
\end{tabular}




\begin{tabular}{|c|c|c|c|c|}
\hline \hline \multicolumn{2}{|c|}{ Table I } \\
PIP Materials Inter-Operational Movement Rate Requirements \\
for Process Feed Materials
\end{tabular}

* The movements indicated by a double asterisks are DWPF operations that will require modification of the existing DWPF building or equipment.

1. AGV - Automated guided vehicle

2. IGTS - Inter-glovebox transport system

3. SVTS - Sample vacuum transport system

4. PCTS - Puck can transport system 
F5.2.1.4 The transport system shall not damage the containers being transported.

R5.2.1.4a The transport system shall have engineered features to prevent significant damage to equipment and structures the system interfaces with or passes through.

F5.2.1.5 The materials handling systems shall handle and transport materials in a safe manner.

R5.2.1.5a As a minimum, the design of the material transport systems shall comply with 29 CFR 1910.

\subsubsection{Plutonium-Bearing Material Transport System General Performance Requirements}

F5.2.2.1 The plutonium-bearing material transport system will perform all movements of plutonium-bearing materials, including waste materials, between unit operation areas in the PIP except for plutonium-bearing sample materials which will be moved by sample vacuum transport system.

R5.2.2.1a Specific material movements made using the plutonium-bearing material transport system are summarized in Table I.

R5.2.2.1b The plutonium-bearing material transport system shall include the following subsystems:

- Lift trucks and pallet handlers - Refer to System Design Description report for materials receipt and storage

- Automated guided vehicles - for moving materials in welded or reusable 3013 containers

- Inter-glovebox transport system - for transporting material not in containment vessels during movements between the confinement systems, structures, and components (SSC) of the unit operations.

- Puck can transport system - for transporting puck cans loaded with ceramic pucks

- Magazine handling system - Refer to the System Design Description report for the canister loading system

- Can-in-canister cask loading and transport (to DWPF) systems - Refer to the System Design Description.report for the canister transport system.

- Can-in-canister movements in DWPF - Refer to the System Design Description report for DWPF receiving and handling

F5.2.2.2 All plutonium-bearing materials shall be confined during all material movements to prevent spread of contamination and to protect employees.

R5.2.2.2a The reusable 3013 containers, weld sealed puck cans and sample containers are containers designed specifically for use in the PIP and shall be designed and qualified as containers to provide for primary confinement of plutonium-bearing materials during material movement. (Note: The 
welded DOE-STD-3013-96 containers have previously been designed and qualified for the containment of plutonium-bearing materials.)

R5.2.2.2b The standard oxide transfer can and the material transfer bucket container will not be designed or qualified as a material containment/confinement container. The IGTS tunnel structure shall provide the primary material confinement during movements where the standard oxide transfer can and the material transfer bucket containers are used to transport plutoniumbearing materials outside of other confinement SSCs such as gloveboxes or the in-process storage vault. (Note: The standard oxide transfer cans and the material transfer bucket will have covers to reduce the spread of contamination during material moves. However, no credit for material confinement shall be taken for the presence of the covers.)

F5.2.2.3 The transport systems shall provide radiation shielding to protect workers operating the equipment or working in areas through which the materials are being transported.

R5.2.2.3a The design for the materials handling systems shall consider the PIP goal for maintaining operator exposures to a maximum of 500 mrem per year and as far below 500 mrem as reasonably achievable. (Based on DOE-STD-112898, Section C.4.3.4, and WSRC Manual 5Q, Article 128.)

R5.2.2.3b The materials handling system for transporting plutonium-bearing materials, not enclosed in shipping packages, shall be designed for automatic or remote operation to reduce employee exposures to radiation.

F5.2.2.4 The transport system shall have engineered features to prevent materials from being arranged in an array that could result in a criticality.

R5.2.2.4a The design of the materials transport system for plutonium-bearing materials shall meet the requirements of DOE Order 420.1 and WSRC documents WSRC-SCD-3 and WSRC-IM-96-133.

F5.2.2.5 The systems shall provide MC\&A capabilities such that the identifications of containers transporting materials are known and can be verified.

R5.2.2.5a The AGV shall have a bar code reader for reading bar codes on containers being transported.

R5.2.2.5b Each unit operation within the plutonium processing containment SSC shall provide for bar code readers at each point where the unit operation interfaces with the IGTS.

R5.2.2.5c Containers transported by the IGTS shall be logged at origin and destination for any transport task. 
F5.2.2.6 The materials transport systems shall be designed to prevent materials being transported from being moved into a geometric array that has a credible potential for initiating a criticality.

R5.2.2.6a Criticality control shall not rely on administrative procedures alone unless a practical engineered control cannot be identified or designed, for the system.

R5.2.2.6b Administrative controls shall be considered for enhancing engineered criticality control features.

R5.2.2.6b Criticality design shall comply with the requirements of DOE Order 420.1.

\subsubsection{Automated Guided Vehicle}

F5.2.2.1.1 The automated guided vehicle (AGV) shall be commercially available equipment modified to support the PIP operational requirements.

R5.2.2.1.1a The equipment shall comply with the requirements of ANSI/ASME B56.5, Safety Standard for Guided Industrial Vehicles and Automated Functions of Manned Industrial Vehicles, 1993

F5.2.2.1.2 The AGV will transport plutonium-bearing materials confined in containers meeting the requirements of DOE-STD-3013-96.

R5.2.2.1.2a The AGV shall transport materials and equipment as indicated in Table I.

R5.2.2.1.2b The AGV shall be capable of receiving or handing-off fully loaded 3013 containers between material on the conveyor from the accountability measurements area and the IGTS vault station.

R5.2.2.1.2c The design shall evaluate the advantages of having equipment for manipulating the 3013 during AGV loading/unloading operations mounted on the AGV versus mounted on the facility materials transfer ports. (Refer to previous requirement)

R5.2.2.1.2d The AGV shall be capable of storing and retrieving 3013 storage containers from vault storage positions.

R5.2.2.1.2d The design shall assume a fully loaded 3013 weighs a minimum of $57-\mathrm{kg}$ (26 lbs).

R5.2.2.1.2e Primary control of the AGV shall be from the storage vault local control room with supervisory control from the main control room.

R5.2.2.1.2f Secondary control shall be provided from the main control room. (Note: control from the main control room requires an enable permissive signal from the conversion and materials handling local control room.

R5.2.2.1.2 $\mathrm{g}$ The design shall be automatically controlled including a guidance system to allow normal AGV movement to be made unattended.

R5.2.2.1.2h The guidance systems shall be a flexible design, non-wire system, allowing for easy path (route) modifications.

R5.2.2.1.2h The AGV shall be capable of navigating around floor obstacles in it normal path (e.g., ladders, tool carts, safety cones, etc.)

R5.2.2.1.2I The AGV shall be capable of carrying and manipulating MC\&A inventory equipment.

F5.2.2.1.3 The AGV will be electrically powered. 
R5.2.2.1.3a EMF generated by the electrical system on the AGV shall not interfere with radio (security) or data transmissions in the PIP or with radiological or safeguards and security monitor equipment.

R5.2.2.1.3b The AGV shall powered by rechargeable batteries.

R5.2.2.1.3c The AGV shall automatically signal the local and main control room when the batteries need recharging. The design shall assure that any operation the AGV has initiated can be completed and the AGV can be selfpropelled to the recharging station after a "low battery" signal has been generated.

F5.2.2.1.4 The AGV shall have features to assure the materials are protected against diversion by unauthorized personnel.

R5.2.2.1.4a The AGV shall have fixturing that will lock the SNM materials containers in place and cannot be moved to an unlocked configuration without concurrence of the conversion and materials handling control room.

R5.2.2.1.4b The AGV shall be equipped with a CCTV for monitoring surrounding personnel proximity to the vehicle.

R5.2.2.1.4c The AGV shall be equipped with an articulating infrared camera.

R5.2.2.1.4d The guidance system shall be designed to be tamper-resistant and have provisions to alarm in the local and main control rooms and central alarm station when unauthorized changes to the guidance system are made.

F5.2.2.1.5 The AGV will be equipped with materials accountability equipment.

R5.2.2.1.5a The AGV shall be equipped with a barcode reading capability suitable for reading barcodes on 3013 containers being received or off loaded and for reading container barcodes while in transit.

R5.2.2.1.5b The AGV shall have data logging capabilities to maintain a seven-day travel history. The data logger shall have provisions to allow the data to be transferred to a facility data logger.

F5.2.2.1.6 The AGV shall have design features to enhance maintenance.

R5.2.2.1.6a Local control of the AGV shall be provided via pendant control with concurrence from the conversion and materials handling control room.

R5.2.2.1.6b The AGV shall have provisions to allow the AGV to be retrieved from any location in the PIP or ASPF-to-PIP tunnel using a second AGV, lift truck, or other equipment designed for AGV retrieval.

R5.2.2.1.6c The AGV shall be provided with automatic diagnostics capable of alerting the conversion and materials handling and the main control rooms of impending maintenance requirements and to aid in maintenance activities in the AGV maintenance room.

R5.2.2.1.6d The AGV shall be equipped to alert the local and main control rooms of non-programmed operations including off-normal shutdown of the AGV.

R5.2.2.1.6e The AGV shall be equipped to alert the local and main control rooms of a failure to acceptably perform a programmed operation.

F5.2.2.1.7 The AGV shall be designed to operate in corridors, hallways, and other areas occupied by personnel. 
R5.2.2.1.7a As a minimum, the AGV shall comply with ANSI/ASME B56.5, Safety Standard for Guided Industrial Vehicles and Automated Functions of Manned Industrial Vehicles, 1993

R5.2.2.1.7b The AGV shall be equipped with both audible and visual devices to alert personnel of the presence of an operating AGV.

R5.2.2.1.7c The AGV shall be equipped with proximity sensors, or other devices, that will shut the AGV down when the AGV approaches or contacts personnel or facility obstructions.

R5.2.2.1.7d The AGV shall be equipped with an easily accessible and identifiable emergency stop button.

\subsubsection{Inter-Glovebox Transport}

F5.2.2.2.1 The inter-glovebox transport system (IGTS) will move materials between the glovebox confinement systems.

R5.2.2.2.1a The IGTS shall be designed to automatically transport and handle containers loaded with metals and oxides not confined by a containment vessel.

R5.2.2.2.1b Each section of the IGTS shall be designed to move materials at the rates indicated in Table I.

R5.2.2.2.1c The IGTS design shall reference the design of containers for transporting materials within the system.

R5.2.2.2.1d The IGTS shall interface with airlocks at each of the process gloveboxes; however, the design of the airlocks is not within the scope of the IGTS system design. Airlock design shall be provided by the respective process areas.

R5.2.2.2.1e The IGTS shall handle payloads between each unit operation utilizing a combination of process level horizontal transports, vertical lifts, and interconnecting overhead tunnels.

R5.2.2.2.1f The IGTS transport technology shall not depend upon specific attributes of the payload being transported. However, the IGTS may use specific payload attributes for payload gripper or payload carrier design.

R5.2.2.2.1g The IGTS control system shall be designed to ensure no collisions between payload carriers.

F5.2.2.2.2 The IGTS shall provide features to minimize the spread of contamination to the extent practicable.

R5.2.2.2.2a The containers used during the movements of materials in the IGTS shall keep the materials in the containers during material movements. These provisions shall include preventing fine materials from being aspirated from the containers by the HVAC airflow in the material transport tunnels. Sintered pucks may be moved on transport trays without containment.

R5.2.2.2.2b The design of the IGTS shall have engineered features to assure that containers being transported cannot tip over or fall-off the transport cart and spill the container's contents. 
The design shall have engineered features to minimize, to the extent practicable, the potential for aspiration, or other mode of transport, of contamination in the unit operation confinement SSCs into the IGTS.

F5.2.2.2.3 The IGTS will be designed for ease of maintenance with periodic gloveports, windows, and repair areas.

R5.2.2.2.3a To the extent practicable, subsystems and components of the IGTS expected to require maintenance or replacement during the life cycle of the system shall be located outside the confinement barrier. This requirement is intended to reduce the potential for the items to be contaminated, for ease of maintenance, and to reduce exposures to maintenance personnel.

R5.2.2.2.3b To the extent practicable, the design of the IGTS shall consider ease of maintenance to minimize the time required to perform maintenance in areas with significant radiation fields. Modularization of components, accessibility and the use of quick-disconnects for electrical, pneumatic, and hydraulic line connections should be considered.

R5.2.2.2.3c The IGTS design shall have provisions for retrieving failed equipment from any location in the system.

R5.2.2.2.3d The IGTS design shall allow for individual payload carriers to be taken "off line" without affecting other payload carriers on the same or adjacent subsystems.

R5.2.2.2.3e All system components located within the gloveboxes shall be readily accessible for maintenance and operation and easily disassembled using common hand tools. Any individual components that cannot be disassembled must weigh less than 20 pounds.

R5.2.2.2.3f Provisions for remotely viewing specific IGTS equipment operations shall be included. At a minimum, CCTV cameras shall provide viewing of IGTS operations at critical points such as payload loading/unloading or at points where payloads are transferred between IGTS subsystems.

R5.2.2.2.3g Maintenance areas must be located in each IGTS transport tunnel for servicing the transport carts and elevator lifts.

R5.2.2.2.3h Viewing windows and gloveports shall be located along the length of the transport tunnels. These windows/gloveports will enable confirmation of the transport cart and SNM container location, repair of a transport cart that will not move, repair of the cart guide rail, retrieval of a SNM can which has fallen off the cart, check for tunnel cleanliness, etc.

F5 2.2.2.4 The IGTS shall use a computer-based motion-control system to manage and coordinate movement of each IGTS subsystem. The design shall be based on open architecture.

R5.2.2.2.4a The control system architecture shall be a distributed control system using an industry standard control architecture and communication protocol (TCP/IP). The architecture shall consist of:

- the materials transport main control computer

- IGTS inter-glovebox tunnel conveyance computers (computers/PLCs) 
- IGTS elevator computers (computers/PLCs)

- Intra-glovebox conveyance computers (computers/PLCs)

R5.2.2.2.4b The IGTS control computer software operating system shall be an industry standard operating system. Specific application programming shall use industry standard software languages. The operating system, languages, and licensing shall be chosen so that availability from multiple sources is guaranteed.

R5.2.2.2.4c The IGTS control computer shall coordinate movement of all IGTS subsystems and act as a traffic controller for payload carriers. The IGTS computer shall also interface with the MC \& A computer and main process control supervisory computer. Material movement requests shall originate from unit operation control computers, local and main control rooms and locally at operator workstations. The IGTS control computer shall be responsible for scheduling and tracking payload move requests from payload pickup points to drop-off points.

R5.2.2.2.4d The main IGTS computer shall keep a history log of all payload carrier movements made within the last seven days. The log shall include bar code identification of each payload (container, tray, etc.) handled by the IGTS.

R5.2.2.2.4e The main IGTS computer shall be capable of reporting the real time position of all facility payload carriers and payload identification number upon request.

R5.2.2.2.4f The main IGTS computer shall be located in the conversion and material handling control room and interface with the main supervisory control computer in the main control room.

R5.2.2.2.4g Each IGTS subsystem (e.g. lift, overhead transport, etc.) shall have a local controller to control movement of the payload carriers within the subsystem. Each local controller shall be capable of local manual operation and maintenance checkout activities.

R5.2.2.2.4h Each subsystem local controller shall be failsafe. If power failure occurs during material movement, payloads shall decelerate to a stop in a controlled, predictable manner. Memory of approximate payload location shall be maintained after a power failure. Payload location resynchronization after power recovery shall involve minimal payload movement.

R5.2.2.2.4 $\mathrm{i}$ The IGTS shall include electrical lockout points to prevent carrier movements during maintenance activities.

\subsubsection{Puck Can Transport}

F5.2.2.3.1 The puck can transport system will move loaded puck cans from the can loading area to the accountability measurement area and, after the puck cans have been nondestructively assayed, will move the puck cans to the magazine loading area.

R5.2.2.3.1a The system shall be designed to move puck cans one at a time with a design basis rate of TBD cans per day. 
R5.2.2.3.1b The design shall be for the puck cans are nominally 3-inch diameter by 20 -inches long and weighing up to 35-pounds.

R5.2.2.3.1c The puck can transport system shall be designed for automatic operation and shall interface with the operation of the overhead robotics crane in the accountability measurements area.

R5.2.2.3.1d The design of the puck can transport system shall interface with the can loading operation, with the overhead robotics crane in accountability measurements area (for both hand-off to the crane and for receiving cans from the crane), and with the can handling equipment in the magazine loading area. Puck Can transfers at each of these interfaces shall be performed automatically.

R5.2.2.3.1e The puck cans shall be transported one-at-a-time, upright, and with minimal vibration loads, impact loads on unsintered puck shall not exceed TBD in-lb and on sintered pucks shall not exceed TBD in-lb, to prevent damage to the sintered pucks.

\subsubsection{Sample Container Transport}

Refer to Section 5.2.5.

\subsubsection{Lift Trucks}

F5.2.2.5.1 Lift trucks shall be used to transport the materials/containers indicated in Table I.

R5.2.2.5.1a Lift trucks shall be electrically operated and, as a minimum, shall satisfy the requirements for Type E lift trucks defined in ASME B56.1, Safety Standard for Powered Industrial Trucks - Low Lift and High Lift, and ANS/UL 583, Electric-Battery-Powered-Industrial Trucks, as implemented in DOE-STD-1090-99, Hoisting and Rigging.

R5.2.2.5.1b The lift truck shall be designed to allow interchangeability of standard forks or drum handling tooling or fixtures.

R5.2.2.5.1c The lift truck shall be capable of interfacing with storage racks/facilities in the various storage rooms including the uranium oxide storage area, ceramic materials storage room, canister receipts storage, etc.

R5.2.2.5.1d The lift truck shall interface with a battery charging system to be located during the Design Phase.

R5.2.2.5.1e The drum fixtures for the lift truck shall be designed to handle standard 55 -gallon drums filled with uranium oxide $\left(\mathrm{UO}_{2}\right)$ with a design basis weight of $900-\mathrm{kg}(2000 \mathrm{lb}$.) per drum

R5.2.2.5.1f The lift truck and fork-type heads shall be designed to lift loads with design basis loads up to $2700 \mathrm{~kg}$. (6000 lb.) based on pallets with up to three drums loaded with $\mathrm{UO}_{2}$.

R5.2.2.5.1g The lift trucks shall interface with delivery trucks at the dock for truck unloading, and loading, operations.

\subsubsection{Hand Trucks and Carts}

F5.2.2.6.1 Hand trucks and/or cart shall be used to transport the materials/containers indicated in Table I. 
R5.2.2.6.1a Hand trucks and carts shall be commercial quality.

R5.2.2.6.1b The need for other motorized hand trucks shall be determined during the Design Phase.

\subsection{3 $\mathrm{UO}_{2}$ Transport System}

F5.2.3.1 The $\mathrm{UO}_{2}$ transport system shall be designed to move drums containing $\mathrm{UO}_{2}$.

R5.2.3.1a The system shall be capable of safely handling either individual drums or palletized drums with up to 3 drums per pallet.

R5.2.3.1b The design shall assume each drum of $\mathrm{UO}_{2}$ can weigh up to 900 kilograms (2000 lbs).

R5.2.3.1c The $\mathrm{UO}_{2}$ transport system shall not significantly damage the drums during handling operations.

R5.2.3.1d The $\mathrm{UO}_{2}$ transport system shall provide for moving drums of $\mathrm{UO}_{2}$ from the main process floor to the $\mathrm{UO}_{2}$ storage area on the second floor.

R5.2.3.1e The $\mathrm{UO}_{2}$ transport system shall provide for moving drums of $\mathrm{UO}_{2}$ from the $\mathrm{UO}_{2}$ storage area to the process location for inputting $\mathrm{UO}_{2}$ in to the ceramic process stack.

\subsubsection{Lift Trucks}

Functions and requirements for lift trucks to be used for handling $\mathrm{UO}_{2}$ drums are included in Section 5.2.2.5.

\subsubsection{Freight Elevator}

F5.2.3.2a A freight elevator shall be provided for moving drums of $\mathrm{UO}_{2}$ and ceramic precursor materials from the main process floor to the third level of the PIP process building.

R5.2.3.2b The freight elevator shall be sized to carry one TBD-kilogram drum plus drum handler lift truck and passengers (Assume a minimum of three passengers.)

R5.2.3.2c The freight elevator shall comply with commercial standards and shall as a minimum comply with the requirements of ANSI/ASME A17.1, Safety Code for Elevators and Escalators.

R5.2.3.2d Warning devices for the elevator, as a minimum, shall comply with 29CFR $1910.306(\mathrm{c})(2)$.

\subsubsection{Non-Nuclear Feed Material, Process Consumables, and Non-Process Materials Transport System}

F5.2.4.1 Operations in the PIP will include moving non-nuclear feed material, process consumables, and non-process materials.

R5.2.4.1a The transport system shall be capable of handling each of the following materials:

- Ceramic precursor - packaging TBD

- Ceramic lubricants - packaging TBD

- Other ceramic additives - packaging TBD 
- Canisters - packaging TBD

- Magazines - packaging TBD

- Puck cans - cartons with up to TBD cans per carton

- IGTS cans, HYDOX baskets, buckets, puck recycle cans - packaging TBD

- Chemicals for halide wash - packaging TBD

- Process support consumables (computer paper, chart paper, janitorial supplies, etc.)

- Maintenance supplies (replacement parts, tools, instruments)

R5.2.4.1b The system shall move the materials from the PIP south dock (including truck unloading) to their respective storage locations.

R5.2.4.1c The system shall move the ceramic precursors, lubricants, and additives from the storage areas to the appropriate input locations.

\subsubsection{Lift Trucks}

Requirements for lift trucks are included in Section 5.2.2.5.

\subsubsection{Hand Trucks and Carts}

Requirements for lift trucks are included in Section 5.2.2.6.

\subsubsection{Freight Elevator}

Requirements for freight elevators are included in Section 5.2.3.2.

\subsubsection{Sample Materials Transport System}

F5.2.5.1 An inter-glovebox sample transport system will be provided to transport process materials samples from the sample source to a sample preparation glovebox.

R5.2.5.1a The sample transport systems shall be vacuum-based pneumatic rather than pressure pneumatic to minimize the possibility of contamination spread in the event of a leak.

R5.2.51b The system will transport sample capsules nominally TBD cm diameter by TBD$\mathrm{cm}$ length and weighing up to TBD gm. when loaded with sample material.

R5.2.5.1c Using a separate sample transport system will decrease the load on the main IGTS system and will decrease the time required for transport of the samples by having a more direct system.

F5.2.5.2 Samples of $\mathrm{UO}_{2}$ and ceramic precursors, binders, lubricants, etc., shall be transported in sample boxes either hand carried or transported on hand trucks.

F5.2.5.2 A system for transferring samples of process materials from the PIP to the 772-F Laboratory shall be provided.

R5.2.5.2a Samples of radioactive materials transferred from the PIP to the 772-F Laboratory shall be transported in shielded containers with emissions from the container to be no greater than TBD mrem per hour at TBD distance from the container surface.

R5.2.5.2b Packaging of the samples for transport outside the PIP shall comply with the requirements of WSRC Manual 19Q, Transportation Safety Manual. 
R5.2.5.2c If the total weight of the loaded sample box is expected to exceed 30 pounds, hoisting equipment shall be provided to assist handling and manipulating the box.

F5.2.5.3 Sample boxes with either radioactive or non-radioactive materials will be transferred to the PIP south dock via hand truck and then to the 772-F Laboratory via site sample truck.

F5.2.5.4 Samples will be transported from the PIP to 772-F using site trucks designated for the transport of radioactive materials.

R5.2.5.4a Transportation of the samples shall comply with the requirements of WSRC Manual 19Q, Transportation Safety Manual.

R5.2.5.1B Site tricks shall be provided from the existing SRS transportation fleet and are . outside the scope of the PIP project.

\subsubsection{Waste Transport}

F5.2.6.1 In the Process Building, waste materials will be transported from its source to the waste management area.

R5.2.6.1a Waste items generated in the processing gloveboxes and sufficiently small shall be transported by the IGST from the respective process confinement systems to waste management area.

R5.2.6.1b Waste items generated in the processing gloveboxes and too large for transport by the IGTS, shall be bagged-out of the gloveboxes and transported via hand truck or cart.

R5.2.6.1c All waste materials generated outside the confinement areas (gloveboxes or vaults) shall be appropriately packaged (typically in plastic bags) and transported via hand truck or cart to the waste management area.

F5.2.6.2 Waste materials packaged in the waste management area will be moved to the PIP south dock for shipment from the PIP.

R5.2.6.2a Drummed TRU waste will be transported using a shielded lift truck with a drum handler head.

R5.2.6.2b Boxed wastes will be transported to the PIP south dock via hand truck or cart.

\subsubsection{Personnel Transport Systems}

The functions and requirements for passenger elevators in the PIP are provided in the architectural sections of the Technical Data Reports for the PIP Process Building and the support buildings.

\subsection{CONCEPT DEVELOPMENT}

\section{Conceptual Design Activities}

Prior to the initiation of Title I design, block flow diagrams will be developed to simulate the movement of all materials in the PIP. These diagrams will verify that all salient material movements have been identified and will corroborate the equipment list for materials handling equipment. These block flow studies will include a preliminary assessment of the impact of nuclear safety and MC\&A on the movement of process materials in the facility. 


\title{
Title I Design Activities
}

A preliminary comprehensive design of the PIP materials handling system will be completed during the Title I design phase. This design effort will include two and three dimensional computer modeling of the systems to assure that the final system design will satisfy all PIP materials handling requirements. These models will be developed by the design $\mathrm{A} / \mathrm{E}$ with oversight by the cognizant Design Authority.

In addition, scale or full-size mock-ups of strategic material movement subsystems will be constructed to verify that the flow of materials through the subsystems will be efficient and to identify potential operational anomalies. These mock-up assemblies will be developed by the design $\mathrm{A} / \mathrm{E}$.

\section{Title II and III Design Activities}

Detailed design of the materials handling systems will be completed during Title II and procurement and construction will be completed during Title III. During these design phases, the computer models will be revised to incorporate changes required due to changes in the overall PIP facility design. The mock-ups may be upgraded if any major changes to the materials handling system are made during these design phases. The mock-ups may also be used for the preliminary training of operations personnel.

\subsection{CODES AND STANDARDS}

Federal Regulations

29 CFR $1910 \quad$ Occupational Safety and Health Standards

\section{DOE Orders and Standards}
DOE Order 420.1
Facility Safety
DOE-STD-3013-96
Criteria for Preparing and Packaging Plutonium Metals and Oxides
DOE-STD-1090-99 for Long-Term Storage
Hoisting and Rigging

Nuclear Regulatory Commission Directives and Guides

The PIP is to be designed and constructed to NRC licensing standards. The DOE and the NRC are currently reviewing low and which NRC Regulations will apply to DOE facilities.

\author{
SRS Procedures and Manuals \\ WSRC-SCD-3 \\ WSRC Nuclear Criticality Safety Manual \\ WSRC-IM-96-133 \\ WSRC-TM-95-1 \\ WSRC Nuclear Criticality Methods Manual \\ WSRC Manual E7 \\ WSRC Manual 19Q \\ Engineering Standards Manual, Standard 01060, Structural Design \\ Criteria \\ Procedure 2.25, Functional Classifications \\ Transportation Safety Manual
}

\section{Commercial Standards}

ANSI/ASME A17.1

Safety Code for Elevators and Escalators 
ANSI/ASME B56.5

ASME B56.1

ANS/UL 583

UBC
Safety Standard for Guided Industrial Vehicles and Automated Functions of Manned Industrial Vehicles, 1993

Safety Standard for Powered Industrial Trucks - Low Lift and High Lift, and ANS/UL 583, Electric-Battery-Powered-Industrial Trucks Electric-Battery-Powered-Industrial Trucks Uniform Building Code

\subsection{REFERENCES}

1. URCL 131617, Revision 1, Design-Only Conceptual Design Report - Plutonium Immobilization Plant

2. WSRC-TR-98-00328, Magnetically Coupled Transport System

3. SMP 99-014, Design Performance Requirements for Standard Transfer Can for Materials Handling in the Plutonium Immobilization Plant 


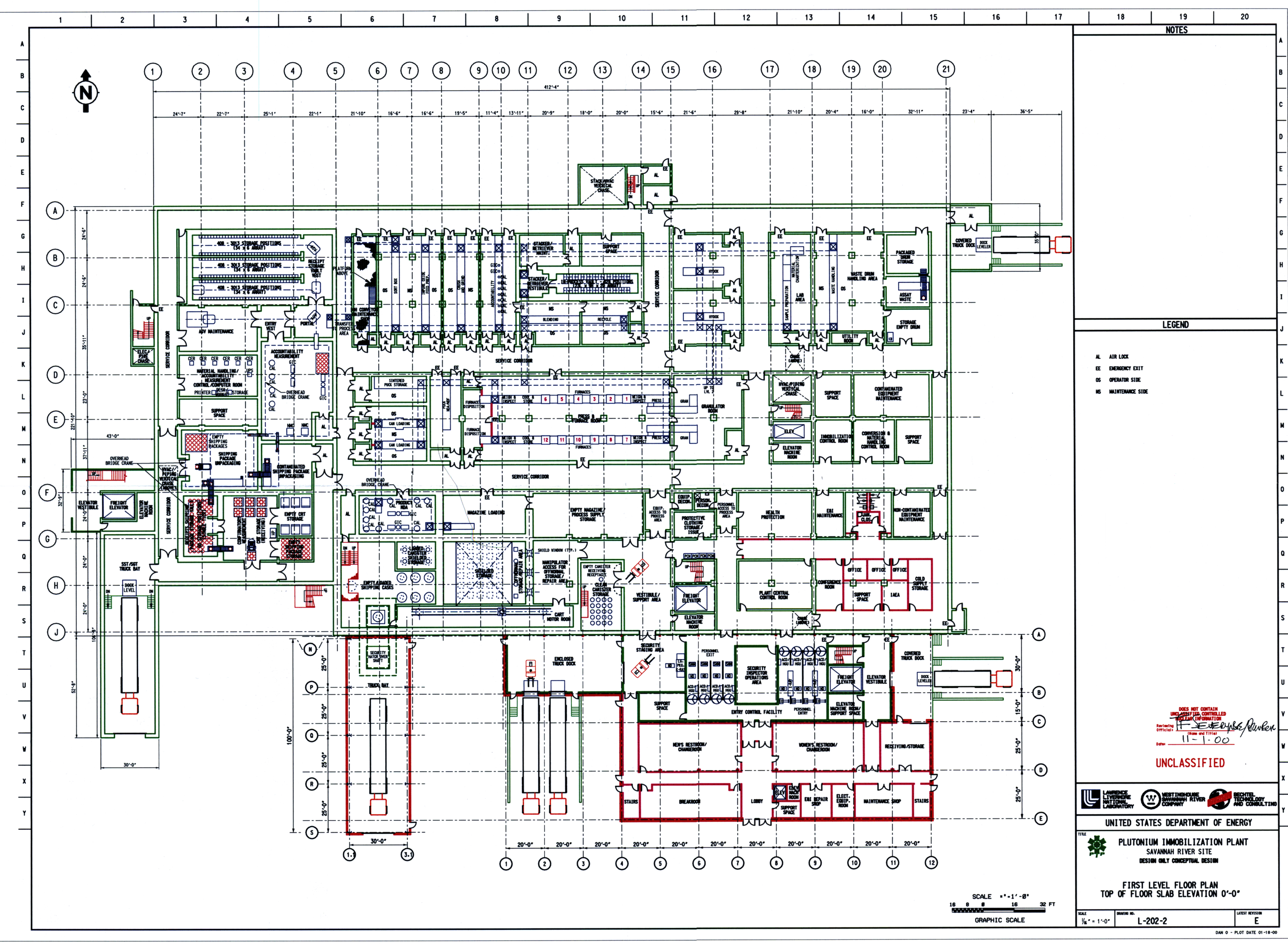

